\title{
Accountability by Numbers: A New Global Transitional Justice Dataset (1946-2016)
}

\author{
Genevieve Bates, Ipek Cinar, and Monika Nalepa
}

\begin{abstract}
In an era of democratic backsliding, scholars and policymakers wonder if failure to reckon with former authoritarian elites and their collaborators plays a role. Yet without adequate data on the way former autocracies and countries emerging from conflict deal with human rights violators, it is hard to tell if new democracies are unstable because of their failure to reckon with their former authoritarian elites or despite it. We introduce a dataset of personnel transitional justice events that allows scholars to answer such questions, disaggregating these events temporally from the date of a country's democratization. The time series nature of our data allows scholars to measure key characteristics of states' dealing with their past and complements existing transitional justice datasets by focusing not only on post-conflict societies and not only on post-authoritarian societies, but on both. To showcase the possibilities our data affords scholars, we use it to develop three novel measures of personnel transitional justice: severity, urgency, and volatility. The granular structure of our data allows researchers to construct additional measures depending on their theoretical questions of interest. We illustrate the use of severity of transitional justice in a regression that also employs data from the Varieties of Democracy project.
\end{abstract}

V e live in an era of democratic backsliding: fragile new democracies are at risk of reverting back to dictatorship. To see examples of this, one need look no further than Poland, Hungary, Turkey, and Venezuela (Bermeo 2016, Lust and Waldner 2015, Serra 2012). Can transitional justice-that is, mechanisms set up by new democracies to deal with former authoritarian elites_-prevent such backsliding from happening? Or is backsliding occurring despite transitional justice provi- sions? To answer these kinds of questions, scholars need to have access to temporally organized data on how states deal with outgoing autocrats, their collaborators, and perpetrators of human rights violations. We introduce such a dataset in a comprehensive and theoretically motivated way.

Transitional justice (TJ) refers to the "formal and informal procedures implemented by a group or institution of accepted legitimacy around the time of transition

A list of permanent links to Supplemental Materials provided by the authors precedes the References section.

*Data replication sets are available in Harvard Dataverse at: https://doi.org/10.7910/DVN/1HCPSG

Genevieve Bates is a Doctoral Candidate in Comparative Politics at the University of Chicago. Her research interests include political violence, post-conflict politics, and transitional justice(genbates@uchicago.edu). Her research focuses on the International Criminal Court, exploring how ICC investigations affect local-level politics and decision-making in the countries where Court involvement is a threat.

Ipek Cinar is a Doctoral Student in Comparative Politics at the University of Chicago (ipekcinar@uchicago.edu). Her research interests include political parties and democracy, authoritarianism and political economy of regime transitions.

Monika Nalepa (D) is Associate Professor of Political Science and a Professor in the College at the University of Chicago (mnalepa@uchicago.edu). With a focus on post-communist Europe, her research interests include transitional justice, parties and legislatures, and game-theoretic approaches to comparative politics. Her first book, Skeletons in the Closet: Transitional Justice in Post-Communist Europe (2010), was published in the Cambridge Studies in Comparative Politics Series and received the Best Book award from the Comparative Democratization section of the American Political Science Association and the Leon Epstein Outstanding Book Award from the Political Organizations and Parties section of APSA. She has published her research in the Journal of Comparative Politics, World Politics, Journal of Conflict Resolution, Journal of Theoretical Politics, Studies in Grammar, Logic and Rhetoric, and Decyzje. 
out of an oppressive or violent social order, for rendering justice to perpetrators, and their collaborators, as well as victims" (Kaminski, Nalepa, and O'Neill 2006). The first association many readers have with transitional justice is the criminal trials of those who committed atrocities in the name of an authoritarian ideology. Indeed, the event that founded the very discipline of transitional justice was the trial of Nazi perpetrators in Nuremberg (Teitel 2000). This association is strengthened by the outstanding efforts of scholars to document trials and amnesties of perpetrators of human rights violations around the world and to organize them in easily accessible datasets. ${ }^{1}$

Our focus here is on personnel TJ-that is, noncriminal forms of TJ. Several factors motivate our interest in elite turnaround at the time of transition from authoritarian rule or violent conflict. For democracy to even have a chance to consolidate, and for peace to have a possibility to take hold, those responsible for human rights violations must at minimum be removed from office. Trials go further. They actually hold those responsible accountable for what they did in the past. Personnel TJ-TJ vetting, truth commissions, and purges, which we define later-can be interpreted as the first step in the direction of accountability. Before trials can take place, the leadership of the former regime must first be removed from positions of power.

Another reason for focusing on personnel transitional justice is that it does not run into the stark problems with the principle of non-retroactivity that criminal trials do. The principle of nulla poena sine lege ("no crime without law") poses a problem for trials of former perpetrators of human rights violations because it criminalizes actions that were not only legal, but indeed encouraged, under the previous authoritarian regime. In the case of trials, the choices of policymakers from different countries are restricted by statute of limitation provisions (Posner and Vermeule 2004; Siegel 1998) or by the extent to which they are able to adhere to Natural Law as opposed to Formalism (Schwartz 2000). Since it is difficult to assess the extent to which different countries' legal traditions restrict their implementation of criminal forms of TJ, we are better able to isolate the effects of TJ if we can assume that each country had available to it the same range of mechanisms. In the case of personnel TJ, it is safe to assume this. Turnover in personnel, which is implied by TJ vetting, purges, and truth commissions, is not as sensitive to the principle of non- retroactivity, regardless of how permissive to the autocrats the law on the books was at the time human rights violations were committed. ${ }^{2}$

Personnel TJ should stand out as critically important for this objective of limiting the influence of former authoritarian elites because it deals with these elites most directly. Yet scholars analyzing data on transitional justice have found little evidence that these mechanisms make a difference in preventing former autocrats from reassert- ing their political dominance (Olsen, Payne, and Reiter 2010a; Binningsbø et al. 2012) or that they matter for democracy in the long run (Olsen, Payne, and Reiter 2010a; Van der Merwe, Baxter, and Chapman 2009; Thoms, Ron, and Paris 2010).

In this paper we demonstrate that the ambiguities in these findings stem from data collection strategies that are not sensitive to the temporal dimension of transitional justice and that fail to adequately categorize personnel transitional justice events. Furthermore, we share preliminary evidence suggesting that disaggregating personnel TJ even further offers insights into the specific features of personnel TJ mechanisms that boost democratic representation. None of these questions could be addressed before knowing when, how, and for how long personnel $\mathrm{TJ}$ has been implemented. Our data brings scholars a big step closer to understanding the impacts of personnel TJ.

In addition to criminal trials, it is important to point out another group of $\mathrm{TJ}$ mechanisms that our data collection effort leaves out. We exclude various forms of victim compensation, which range from the return of expropriated wealth in monetary substitutes or in kind to purely symbolic public apologies. Such formal apologies can be successful or can fail to accomplish reconciliation between nations. ${ }^{3}$ We leave them out to concentrate on elite turnover; the effect of victim compensation on authoritarian elites is at most secondary to this focus.

The next section will motivate our data collection project in more detail while reviewing the extant research on quantitative approaches to transitional justice. We next introduce the concept of TJ events, the building blocks of our measures. We divide these into progressive and regressive events, which for any given country can be visualized as trend lines. To showcase the possibilities a disaggregated event-based dataset affords, we then construct and apply measures of personnel transitional justice: severity, urgency, and volatility. We apply these measures in a regression framework to predict authoritarian turnover, using a variable from the Varieties of Democracy Dataset (Coppedge et al. 2017a), and use this regression framework to argue for disaggregating personnel transitional justice further.

\section{What We Know about Personnel Transitional Justice}

Data on personnel TJ mechanisms is notoriously hard to collect, in no small part because policy makers in different parts of the world refer to these mechanisms using different general terms ranging from "vetting" and "purging" to "house-cleaning," or specific terms such as "de-nazification," "de-communization," or "de-baathification." This is probably why both many researchers and most databases pool all personnel TJ events under one heading of "purges" or "lustration." Researchers who have 
contributed theoretical accounts of TJ such as Jon Elster (2004) as well as scholars who have developed datasets of personnel $\mathrm{TJ}$ treat lustration and administrative purges (such as de-communization, de-baathification, and denazification) as the same type of mechanism for dealing with the past.

Authors of the widely recognized Post-Conflict Justice Database (Binningsbø et al. 2012) refer to all personnel forms of TJ with the term purges, which describes "the acts of removing politicians, members of the armed forces, judiciary ... for their (alleged) collaboration with or participation in a conflict and limiting their influence accordingly" (Binningsbø et al. 2012, p.736). In part because their data collection effort is limited to societies recovering from conflict and only covers the first five postconflict years, these authors only managed to locate fifteen post-conflict episodes that are followed by purges thus defined. Olsen, Payne, and Reiter similarly pool personnel TJ mechanisms into one category, calling it lustration. They define lustration as "the mechanism that occurs when the state enacts official policies denying employment in public positions to individuals because of their former political acts or identity" (Olsen, Payne, and Reiter 2010a, p.38). Using this definition, these authors were only able to record fifty-four instances of lustration, mostly in Eastern Europe. ${ }^{4}$

In a recent paper, Cynthia Horne (2017a) underscores the failure to distinguish between lustration and purges. Citing Monika Nalepa (2013), she defines the former as "a form of vetting - the set of parliamentary laws that restrict members and collaborators of former repressive regimes from holding a range of public offices, state management positions, or other jobs with strong public influence (such as in the media or academia) after the collapse of an authoritarian regime" (Horne 2017a). Purges, meanwhile, extend collectively to members of organizations linked to the ancien régime. Thus, whereas lustration denotes a procedure that considers each case individually, purges presume collective responsibility. Horne notes further that lustration is part of a more general category of vetting, which she defines as any ban on holding office, not limited to members or collaborators of the ancien régime. Aligning with the criticism laid out by Horne, we believe that the negligible effects of personnel TJ mechanisms on the quality of democracy identified by Olsen, Payne, and Reiter and Binningsbø et al. may have at their roots the failure to separate purges from lustration. ${ }^{5}$

Roman David takes a similar disaggregating approach, but limits the scope of lustration to Eastern Europe. He justifies this decision with the fact that prior to 1990 , this term was not used to describe transitional justice procedures (David 2011, p.67). ${ }^{6}$ While it is true that the term lustration was rarely used outside of Eastern Europe to describe the disqualification for public employment of secret and clandestine collaborators with the former re- gime, our data reveal that such procedures were implemented both before 1990 and beyond Eastern Europe. Consider as an example the Portuguese decree from March 22 1975, stipulating that any member of the armed forces who was found to be "incompetent" or not prepared to make a declaration of loyalty to the MFA could be placed on the reserve. Under the same decree, all military members involved in the coup attempt of March 11 of that year were expelled from the forces and their property confiscated (Pinto 2001).

The failure to distinguish purges from lustration is one problem with existing data. Another is the difficulty scholars face when trying to pinpoint when exactly a mechanism of a certain type was implemented. This has led many researchers to aggregate all $\mathrm{TJ}$ activity of a certain type into a single variable that signifies the presence or absence of that transitional justice mechanism in a given country. Noteworthy in their attempt to surmount these problems are efforts by the Transitional Justice Database (TJDB) team (Olsen, Paine, and Reiter) and the Transitional Justice Research Collaborative. ${ }^{7}$ Both record the year in which a transitional justice mechanism of a given type was implemented, allowing a country to have multiple events. While these datasets offer a considerable improvement over treating TJ mechanisms as "one-shot" events, they still condense much of the process and assume away the possibility of reversals (Bakiner 2016). Furthermore, particularly in the case of personnel TJ, it is hard to exactly pinpoint a decisive moment when these mechanisms are implemented. Instead, legislation is frequently first proposed, then amended, eventually passed. Following this, it is sometimes struck down by a constitutional court or presidential veto, only to be reintroduced on the legislative floor again. Moreover, with the passage of time, the scope of transitional justice mechanisms can be expanded or curtailed, or the legislation can be completely revoked. Data projects trying to identify a specific year in which a procedure was finally implemented reduce transitional justice to a oneshot event. Ignoring the temporal nature of these processes assumes away their nonlinearity. Documenting the entire process of personnel $\mathrm{TJ}$ as it unfolds over time requires fewer judgment calls and is able to account for regressive changes in personnel TJ implementation. Finally, a byproduct of the panel structure of our data is that it allows scholars to employ research designs that are not available to them with just cross-sectional structures. At the same time, all research designs suitable for cross-sectional formats can also be used. One can do with disaggregated data anything that is possible with aggregated data, though not the other way around.

\section{Data Collection and Organization}

In sum, existing TJ datasets either mischaracterize the complexity of the $\mathrm{TJ}$ process by identifying one year 
when a mechanism of a given type was implemented or fail to distinguish between $\mathrm{TJ}$ vetting ${ }^{8}$ and purges. In this section, we explain our own data collection strategy, which resolves both of these problems. We also show how temporally coded data allows us to develop measures of urgency, severity, and volatility of personnel transitional justice. Applying these measures to our data captures just how much information is missed when personnel TJ is summarized solely by the year of implementation.

\section{Categories of Personnel Transitional Justice}

We begin by explaining how we divide personnel transitional justice events into three categories: purges, TJ vetting, and truth commissions.

Purges. A purge denotes the disbanding of an entire segment of an ancien régime institution without discriminating between leaders (those issuing orders) and rank and file (those following orders). Some illustrations of purges come from post-communist Europe and involve the disbanding of communist secret police agencies. The purging of the East German Stasi is now legendary and described by multiple historians and political scientists (Koehler 1999; Childs and Popplewell 2016; Miller 1998). Initially, following Erich Mielke's resignation, the East German Council of Ministers renamed the Stasi the "Office for National Security." However, less than two months later, the new Prime Minister of the German Democratic Republic, Hans Modrow, ordered the dissolution of this new office. The Ministry of Internal Affairs inherited the buildings and facilities of the former Stasi, but none of the employees were rehired by the new agency. ${ }^{9}$ The Ministry took over some of the tasks performed by Stasi (notably, the ones that did not involve spying on the opposition). This thorough purge came at a cost, however. Numerous journalistic accounts document the gainful employment of former Stasi officers in the business holdings of Martin Schlaff, an Austrian businessman; in the 1980s, Schlaff made a small fortune by supplying senior Stasi officers with products that were precluded from trade under "CoCom," following an embargo imposed on the Soviet bloc (Tillack 2007; Borchert 2006).

Of course, purges need not be limited to the secret intelligence and police apparatus. The following illustration comes from Panama, where a Human Rights Watch report describes a purge of the judiciary: "From top to bottom, judges who held posts under Noriega resigned or were purged and have been replaced by new ones, almost all of whom lack prior judicial experience: all nine of the Supreme Courts judges resigned and were replaced; the newly-constituted Supreme Court then dismissed or had to replace 13 out of the 19 judges of the Tribunales Superiores, the intermediate appellate courts; and approximately two-thirds of the 48 trial- level circuit judges, were, in turn, removed or replaced by the newly appointed appellate judges" (Human Rights Watch 1991).

One final illustration of a purge comes from Argentina, where according to The New York Times, only two months after taking office, President de la Rua purged the intelligence apparatus of over 1,500 agents responsible for involvement in the so-called "dirty war" (Krauss 2000). Purged agents were either dismissed or forced into retirement. Instead of releasing the list of names of those purged, entire sections of the agency were let go, suggesting that no discrimination was made between those giving or following orders, or based on the level of involvement. According to the report, this "housecleaning ... mean $[\mathrm{t}]$ nearly a $50 \%$ reduction in military intelligence personnel, and officials said they would leave nonmilitary intelligence work to civilian agencies" (Krauss 2000).

Transitional justice vetting. TJ vetting, as explained earlier, is a form of vetting and refers to restricting access to public office of members and collaborators of the former repressive regime. ${ }^{10}$ The restrictions may come in the form of an outright ban on running for office or by way of distributing the information about the candidate's involvement to voters or the relevant nominating agency. An example of a TJ vetting mechanism is Albania's September 1995 "Law On Genocide and Crimes against Humanity." ${ }^{11}$ This law excluded members of the politburo, the Central Committee, and the parliament, as well as former secret police agents and informers, from government, parliament judiciary, and mass media positions. What distinguished this law from a purge was Article 3 of the law, which "excluded those persons who had held an enumerated position, but had acted against the official line and distanced themselves publicly" (Hatschikjan, Reljić, and Šebek 2005, p.37). This provision ensured that the responsibility of a collaboration with the ancien régime gime was not collectively attributed, as with a purge, but rather individual. We provide more examples of TJ vetting in the section "Disaggregating Personnel Transitional Justice Further."

Truth commissions. Truth commissions are "bodies set up to investigate a past history of human rights abuses in a particular country, which can include violations by the military or other government forces or armed opposition forces" (Hayner 1994). According to Hayner, in order to be considered a truth commission, the body should (1) not focus on ongoing human rights abuses as a human rights ombudsman might; (2) examine a pattern of human rights abuses over time rather than a specific event; (3) be temporary; and (4) have an official sanction from the state to carry out its operations (Hayner 2001, p.14). Onur Bakiner offers more nuance to this definition by distinguishing truth commissions from "similar investigatory, judicial, or commemorative practices and institutions, 
such as parliamentary human rights commissions, courts, monitoring institutions and NGO's truth finding efforts" (Bakiner 2016, p.11). Departing from Bakiner's distinctions, we decided against excluding commissions of inquiry that examine human rights violations committed in more specific events than an entire period of authoritarian rule or civil war; we consider this inclusion justified as we include in our data commissions that only partially completed their mandate.

A classic example of a truth commission is the South African Truth and Reconciliation Commission (Hayner 2011, Gibson 2006). The Commission was formed in 1995 to investigate crimes committed against the South African people during the apartheid regime (19601994), covering human rights violations committed by both the state and various liberation movements. ${ }^{12}$ The Commission's mandate provided it with the ability to offer amnesty to those who fully participated in the process and truthfully confessed the full extent of their crimes. It released a five-volume final report to thenPresident Nelson Mandela in 1998. The report detailed the abuses committed by the apartheid-era National Party government, the African National Congress (ANC) — the state opposition turned ruling party-and other "leading political figures on both sides of the antiapartheid struggle” (Keesing's Record of World Events 1998).

While the South African Truth and Reconciliation Commission is arguably the best-known truth commission, such commissions have existed all over the world and in many different forms. A lesser-known example was established in Thailand in 2010 by the Abhisit Vejjajiva government (Rustici and Sander 2012). The Commission had a two-year mandate, working from July 2010 until July 2012 to investigate the 2010 political violence that emerged as a result of protests initiated by the United Front for Democracy against Dictatorship (UDD). It released interim reports every six months and produced a final report on September 17, 2012; the report identified those responsible for the 2006 military coup, a polarized media, and differences in the understanding of democracy as prominent root causes of the violence (Truth for Reconciliation Commission of Thailand 2012, 327-30). ${ }^{13}$

\section{Personnel Transitional Justice as a Time Series}

Mechanisms for dealing with righting wrongs committed by former ruling elites and commentary on these wrongs date back to the ancient Athenian democracy and its attempts to deal with crimes committed by the Thirty Tyrants (Todd et al. 2000). For obvious reasons, our dataset cannot cover a time span stretching back to the fifth century B.C. Adhering instead to conventions in the conflict literature (Kreutz 2010; Olsen, Payne, and Reiter 2010b; Sikkink and Walling 2007; Binningsbø et al.
2012), we document the occurrence of these mechanisms in all countries that experienced civil war or transitioned to democracy between 1946 and 2016. Globally, there are eighty-four such states.

Our country selection criteria build on the existing Autocratic Breakdown and Regime Transitions (GWF) dataset (Geddes, Wright, and Frantz 2014) and the PostConflict Justice (PCJ) database (Binningsbø et al. 2012). We select countries that, as indicated by the Autocratic Breakdown and Regime Transitions dataset, transitioned from a military, personalist, or party-based authoritarian regime in the post-1946 period. We include countries that are no longer democratic, but that experienced a democratic spell after $1946 .{ }^{14}$ Our dataset also encompasses countries with multiple indicators of regime type, such as Burundi, which transitioned in 1993 from a militarypersonal regime, or Indonesia, which transitioned from a party-personal-military regime. We exclude all countries that are currently authoritarian and have remained authoritarian for most of the post-1946 era; by our definition these countries are unable to implement transitional justice.

As far as democracies that have experienced conflict are concerned, we began by following exactly the same criteria as the PCJ database; that is, we included all armed conflict episodes that have ended in the 19462006 time period. While the PCJ database has a conflictepisode structure, we aggregated the conflict episodes identified in the PCJ dataset to the country level, and removed all long-term authoritarian regimes that never became democracies in order to remain consistent with the rest of our data.

If a country dissolved into a collection of smaller countries as a result of successful secession efforts, as Czechoslovakia and Yugoslavia did, we included any relevant transitional justice events from the original country as the transitional justice events for the most relevant successor country. All additional countries were coded as having transitioned at the date of independence. For example, we coded the Czech Republic as the successor country following the 1993 dissolution of Czechoslovakia. The Czech Republic thus inherited the post-1989 transitional justice events attributed to Czechoslovakia. Slovakia was then coded as having transitioned in 1993. Serbia was coded as the successor country to Yugoslavia, while Slovenia, Bosnia and Herzegovina, Croatia, Macedonia, Kosovo, and Montenegro were all coded as having transitioned at their respective dates of independence.

Finally, we included information on countries and conflict periods that led to transitional justice but that had been excluded from previous datasets. ${ }^{15}$ We chose explicitly to include small countries because such countries are immune neither to periods of authoritarian rule nor to periods of conflict, and, as seen in the cases of East Timor 
or Kosovo, can implement all forms of personnel transitional justice.

To create our dataset, we start with two major electronic databases; Keesing's Record of World Events and Lexis Nexis Academic Universe. The raw data include chronologies of events pertaining to purges, TJ vetting, and truth commissions for all countries satisfying the selection criteria outlined earlier. We searched them for information about events related to purges, TJ vetting, and truth commissions in all relevant countries, beginning from the date of the transition to democracy, the start of the post-conflict period, or both (in the case of conflicts that occurred in democracies), and ending in either 2016 or the year in which the country reverted to authoritarianism.

There are, of course, serious limitations to relying on electronic databases alone. For example, they are biased towards large countries and countries with authoritarian regimes and conflicts that are better penetrated by the network of human rights oriented NGOs and journalists. For this reason, we supplement our database searches with numerous secondary sources ranging from articles to historical accounts in the form of monographs and chapters in edited volumes. ${ }^{16}$

Based on these searches, we created a chronology document for each country. The chronology includes relevant information about the final authoritarian regime and transition, conflict and post-conflict period, or both. We then provide records of each TJ event in chronological order, including the date, a brief identification of the event, the relevant state and non-state actors, a more detailed description of the event, and the source where the information was obtained. In order for a personnel TJ event to be relevant, it must include an actor in his or her governing capacity enabling (in a progressive event) or disabling (in a regressive event) the pursuit of personnel TJ.

To be more specific, we define a progressive $\mathrm{TJ}$ event as the submission of a TJ proposal to the floor of the legislature, the passage of such legislation, the upholding of such legislation as constitutional by a supreme court, or the overturning of a presidential veto against such legislation. In the case of truth commissions, the publication of the commission's report(s) and the extension of the commission's mandate are also considered to be progressive TJ events. We define a regressive transitional justice event, in contrast, as the voting down, vetoing, or striking down by the constitutional court of a transitional justice proposal or law. Similarly, expanding the set of persons targeted by TJ or broadening the set of "offenses" (where "offense" is defined in light of the TJ procedure in question) to include more past or present positions constitutes a progressive transitional justice event, whereas attempts to narrow the set of targets or "offenses" are coded as regressive $\mathrm{TJ}$ events.
The guiding principle in determining if an event is regressive or progressive is whether it advances the $\mathrm{TJ}$ process forward or shifts it backward. An event is considered progressive if it strengthens the $\mathrm{TJ}$ process in question, and regressive if it weakens the process. ${ }^{17}$ Consider Onur Bakiner's 2016 observation that some truth commissions were disbanded before they could finish their work (examples provided by Bakiner include Indonesia, Turkey, Mexico, and Nepal). The temporal organization of our data, which accounts for progressive as well as regressive events, allows us to account for such setbacks in the work of truth commissions.

After assigning each event to one of three categoriespurge, TJ vetting, or truth commission-we coded it as progressive or regressive. Events that were not relevant for the dataset were labeled as such, with an explanation of why the event was excluded.

The number of progressive and regressive TJ events was then aggregated to create an annual panel, with countries as the cross section and time since transition as the temporal dimension. A panel assembled in this way allows for the creation of many different measures of personnel transitional justice. In addition, the raw chronologies themselves allow researchers to experiment with different systems of disaggregation. ${ }^{18}$

A time series of progressive and regressive transitional justice events can also produce trends for individual countries. Figure 1 presents the trends for the truth commission processes in Nigeria, with the gray line representing regressive and the black line representing progressive events. Almost immediately after Nigeria's 1999 transition to democracy, President Obasanjo appointed the Human Rights Violations Investigation Commission (Oputa Panel) to investigate human rights abuses that had occurred from 1966 to 1999 (Ughegbe 2003). By 2001, however, a challenge against the Commission had been initiated, and a Federal High Court asked the Court of Appeal to review the legality of the Commission's existence (Anaba 2001). Despite the court challenge, the Commission released its report to President Obasanjo in 2002 (United States Institute of Peace $2011 \mathrm{~g}$ ). Shortly after the report was released, the Supreme Court ruled on the challenge, agreeing that the Commission's original mandate was unconstitutional (Ughegbe 2003). As a result of the Court decision, in December 2005, the Obasanjo government decided not to publish the report, though civil society ultimately did (Pambazuka News 2005).

The close succession of regressive events following progressive events described in the Nigerian narrative is well captured by the trends in figure 1. Recall that these trends should not be interpreted as periods when personnel transitional justice was implemented, though they may be correlated with those periods. Instead, the black line represents the number of events each year 


\section{Figure 1}

Regressive (gray) and progressive (black) truth commission events in Nigeria

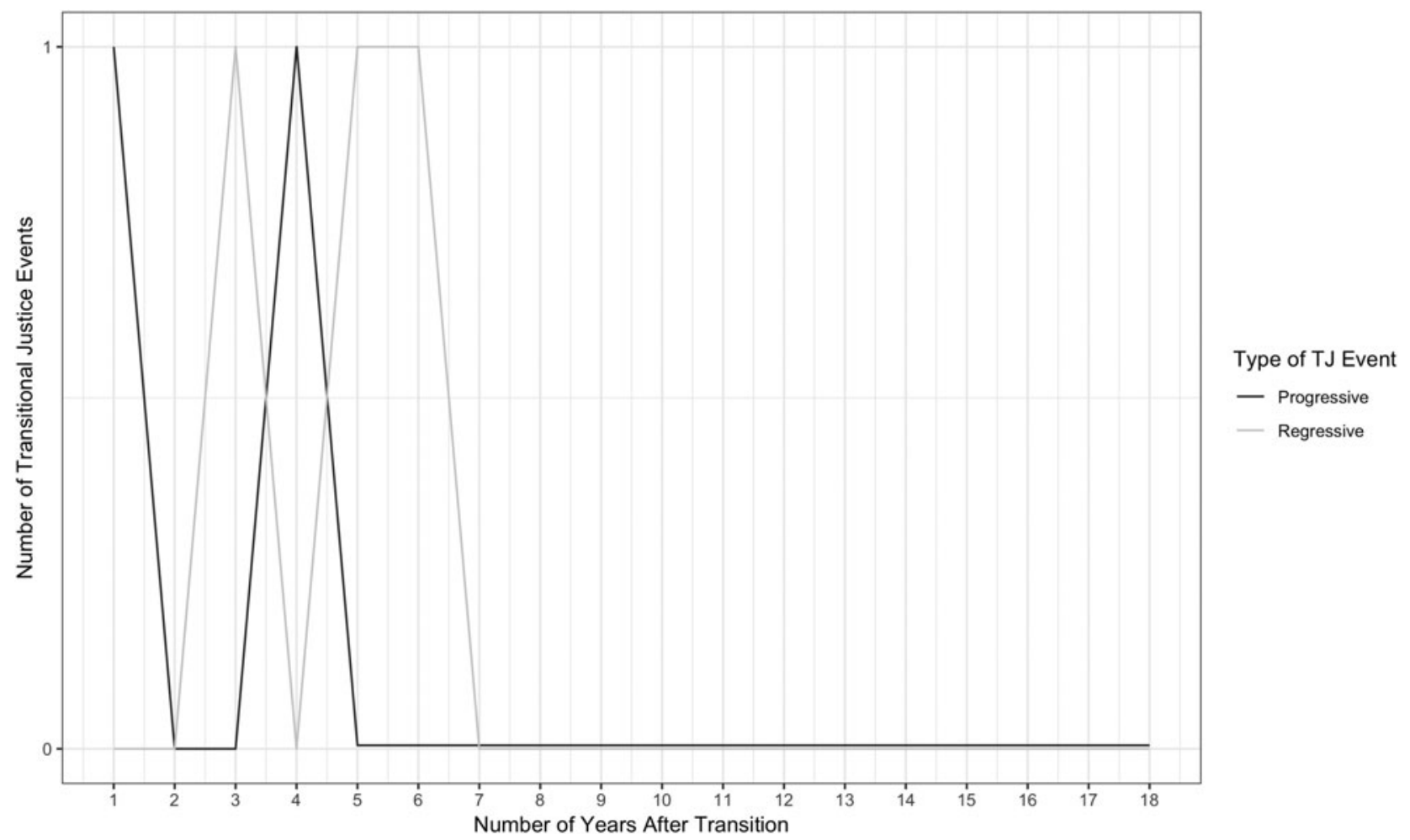

since the transition moving the truth commission process closer towards releasing a report, while the gray line represents the number of events impeding the truth commission process. ${ }^{19}$

We can think of the trends such as the one created for Nigeria in figure 1 as building blocks out of which scholars can construct measures pertaining to various aspects of personnel TJ. In the next section, we offer examples of three such measures and illustrate how one of them may be used to address the question motivating this article.

\section{Constructing Measures of Transitional Justice}

Measures are never constructed in complete abstraction from research questions (Goertz 2006; Coppedge 2012). Our dataset collection and this specific article are motivated by the question of how dealing with former authoritarian elites impacts the quality of democratic representation. However, "dealing with former authoritarian elites" could mean dealing with them harshly rather than mildly, or not at all; dealing with them immediately instead of years after the transition; or being consistent in pursuing a certain type of personnel transitional justice process. In order to capture these three aspects of dealing with former authoritarian elites and their collaborators, we develop three measures that use our yearly progressive and regressive personnel TJ events as building blocks: (1) urgency and delay, (2) severity, and (3) volatility. We introduce each in turn.

\section{Urgency and Delay}

The intuition behind measures of urgency is to capture how long a country waits for a TJ event. The most straightforward measure would count the number of years lapsed before the first progressive transitional justice event as a proportion of years lapsed since the transition itself. Herein, however, lies the problem with the censored nature of our data. Should a country that transitioned five years ago and implemented TJ vetting in its fourth year of transition be equivalent to a country that transitioned twenty years ago and implemented TJ vetting only four years ago? The naïve measure of delay proposed above would give both a score of .8 . Yet the latter country seems to be more of a latecomer to the TJ vetting process than the former.

Importantly, it is hard to vet elites for collaboration with the authoritarian regime in the immediate aftermath of transition. In contrast to purges, vetting may rely on 
uncovering and organizing files of the secret political police, an activity that may take years depending on how well organized the archives of the secret political police were to begin with. Similar delays caused by the very nature of unearthing evidence plague truth commissions. In order to account for such startup costs, we propose to measure urgency/delay for each country with: ${ }^{20}$

$$
U=\frac{T^{N}-P^{1}}{\left(T^{N}-T^{1}\right)\left(P^{1}-T^{1}\right)}
$$

where $T^{N}$ is 2016 or the last year of the democratic spell before the country's reversal to authoritarian rule, ${ }^{21} P^{1}$ is the first year following the country's transition with a progressive personnel transitional justice event, and $T^{1}$ is the first year following the country's transition. ${ }^{22}$ To understand how this measure works, consider figure 2:

In the numerator, $T^{N}-P^{1}$ corresponds to how soon the first progressive TJ event occurs. The larger its value, the more urgent is the implementation of personnel TJ. The denominator contains two expressions: (1) the length of the democratic spell, $T^{N}-T^{1}$, which is used to account for the fact that countries with longer democratic spells have more opportunities to engage in transitional justice, and $(2)\left(P^{1}-T^{1}\right)$, a weight capturing the number of years lapsed before the first progressive TJ event. Both of these expressions decrease the value of the urgency measure.

$\mathrm{U}$ assumes the value of zero when a country has no progressive TJ events. Given that urgency and delay are a function of time, a country that has not yet implemented a particular type of $\mathrm{TJ}$ cannot possibly have a non-zero value for the measure. The measure will approach the value of 1 when $\mathrm{P}^{1}$ approaches $\mathrm{T}^{1}$-that is, when the first progressive event occurs very soon after the transition. Because $\mathrm{T}^{1}, \mathrm{~T}^{\mathrm{N}}$, and $\mathrm{P}^{1}$ can only take up positive integer values and $\mathrm{T}^{1}<\mathrm{P}^{1}$, the measure will never actually assume 1 . The measure is also well defined (the denominator cannot be zero). ${ }^{23}$ For a substantive

\section{Figure 2}

\section{Measure of urgency}

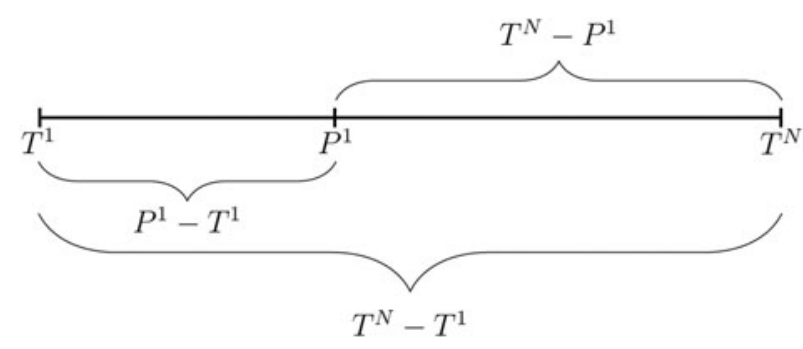

illustration of the urgency measure, figure 3 presents its values for our universe of $\mathrm{TJ}$ vetting events. This exercise captures the tremendous simplification that occurs when scholars try to capture the variation in implementation of transitional justice with a dummy variable. Clearly, the extremely delayed vetting in Spain cannot be treated as equivalent to the urgently implemented vetting in Greece. While Spain transitioned to democracy in 1976, it did not begin a TJ vetting process for nearly forty years, until a proposal to declassify military reports from the Franco era was made in the legislature in 2013 (Congreso de los Diputados, Comisión de Cultura 2013). Greece, however, began its vetting process almost immediately after its July 1974 transition, removing the leadership of the armed forces, police, and banking and public sector by mid-August that same year (Alivizatos and Diamandouros 1997; Keesing's Record of World Events 1974). ${ }^{24}$

\section{Severity}

Among those evaluating personnel transitional justice, there is a high demand for an instrument that would capture its intensity. Such a measure should place the severity of a personnel transitional justice procedure somewhere between the two extremes of minimal and severe. One way to approach this is by taking the cumulative effect of relative changes in the law since the transition as follows:

$$
S=\frac{\sum_{t}\left(P^{t}\right)}{\sum_{t}\left(P^{t}+R^{t}\right)+1}
$$

where $\mathrm{t}$ is the subscript over time, $R^{t}$ is the number of a country's regressive events in period $t$, and $P^{t}$ is the number of progressive events in period $t$. This measure is simply the total number of progressive events over the total number of events. In a country with no personnel transitional justice, $S$ will obviously take on 0 ; the " +1 " in the denominator ensures that the measure is well defined. The more progressive events a country has among its total events, the closer its score is to 1 . Figure 4 applies this measure to purges.

Even though existing datasets treat all purges as equal and the same, our measure demonstrates a fair degree of variation. Figure 4 ranks purges from least (Comoros) to most (Latvia) severe. In Latvia, post-transition governments initiated a series of purges that banned anyone who had been active in the Soviet Communist Party or its affiliate organizations from running for office. These bans were upheld despite numerous court challenges throughout the 1990s and 2000s (Stan et al. 2009). This differs starkly from Comoros, where a weak purging of the military was initiated after it transitioned to democracy in 2006. Several years later, the purge in Comoros was 


\section{Figure 3 \\ Urgency of transitional justice vetting}

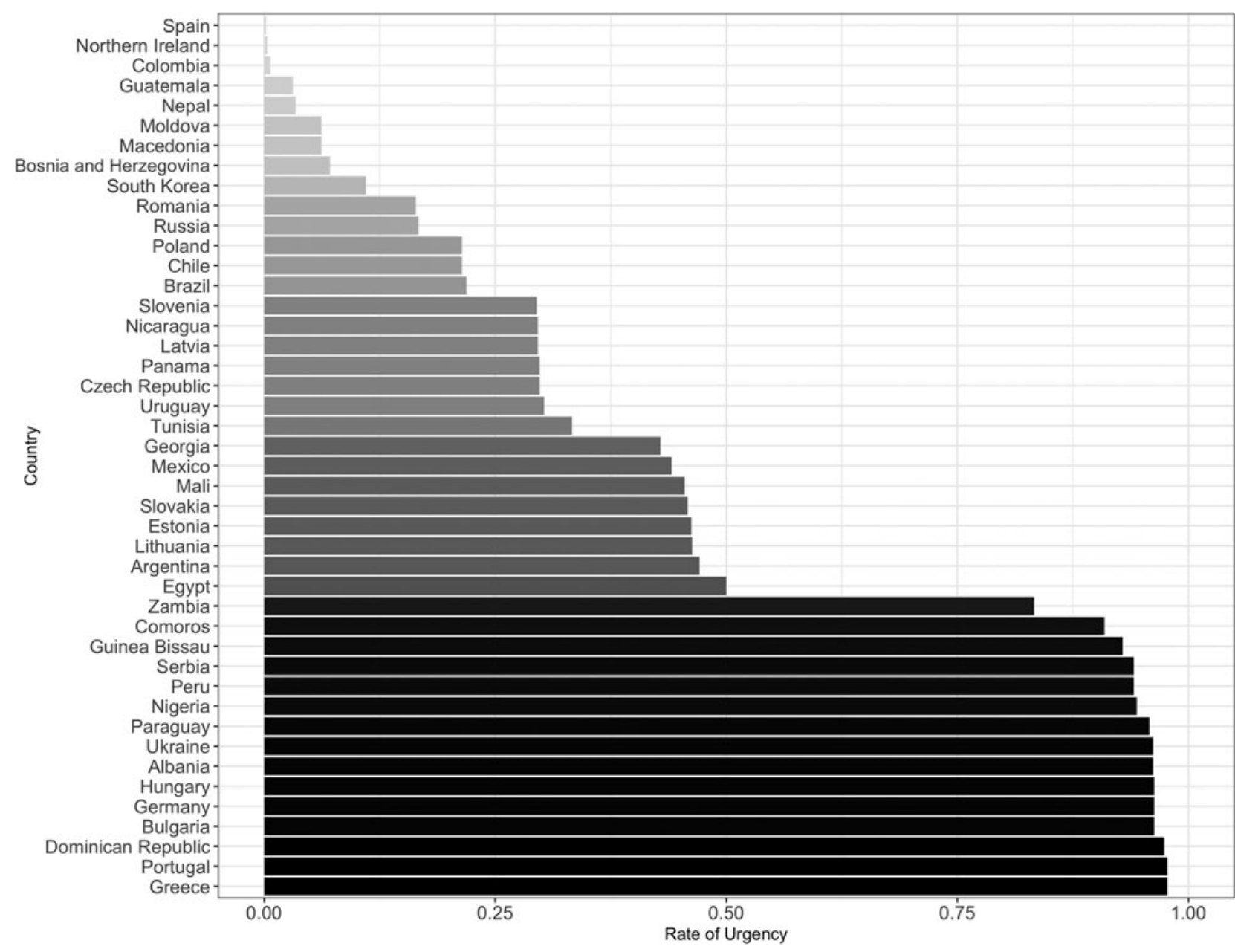

undone, and the "militia" loyal to the previous regime were reintegrated into the military (UN Integrated Regional Information Networks (Nairobi) 2011).

As further insight into the usefulness of our severity measure, consider table 1 , which compares its application to lustration from TJDB and vetting from the Transitional Justice Research Collaborative. While the event counts implied by TJDB and TJRC equate countries like Albania and Argentina-with two lustration events for TJDB, and two and three vetting events, respectively, for TJRC_-our measure of severity shows a clear distinction between the two countries: TJ vetting in Argentina was significantly more severe (.83) than TJ vetting in Albania (.55). Albania, in fact, has much more in common with Bulgaria (.59), which has three lustration events according to TJDB. As shown in table 1, the nature of our disaggregated data allows for a more nuanced understanding of the severity of personnel transitional justice.

\section{Volatility}

In order to capture the stability and consistency of transitional justice, we focus on the volatility in support of a transitional justice mechanism of a given type in a given country. We measure volatility with the magnitude of policy swings in the transitional justice mechanism in question. Policy swings are dramatic shifts from progressive to regressive events or vice versa. Therefore, our volatility measure only applies to countries that have experienced both progressive and regressive events. Volatility could be simply measured by the number of years lapsed between when the maximum number of progressive events occurred and the maximum number of 


\section{Figure 4 \\ Severity of purges}

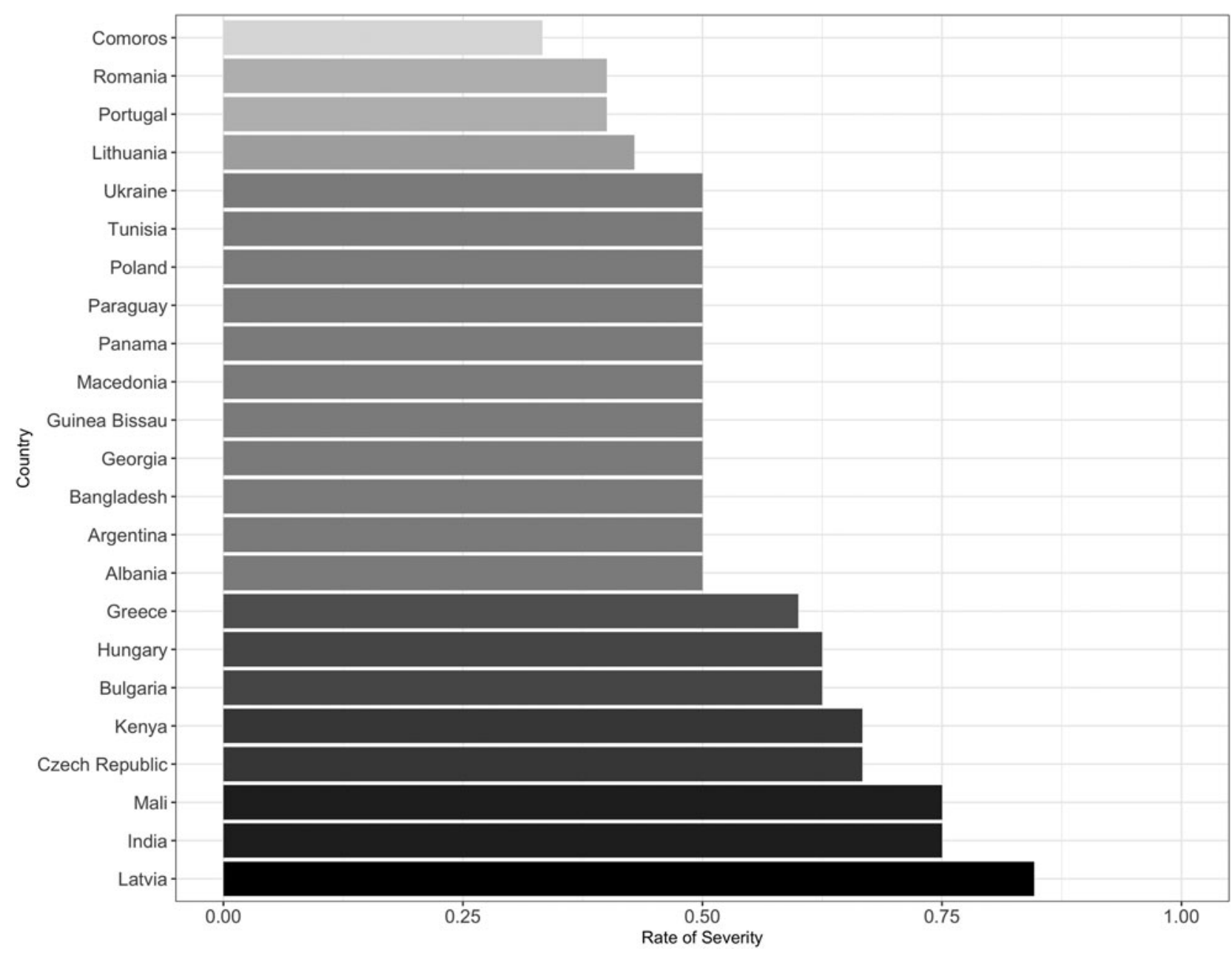

regressive events took place. Such a measure, however, would fail to account for the fact that a country can experience both progressive and regressive events over the course of the same year. Thus, in order to capture this net value of progressive and regressive events, we propose: of progressive events. Thus, $\max _{t}\left\{\left(P^{t}-R^{t}\right)\right\}$ is the maximum of net events, and $\min _{t}\left\{\left(P^{t}-R^{t}\right)\right\}$ is the minimum of net events. The difference between these two expressions, which constitutes the numerator in our measure, captures the policy swing in personnel $\mathrm{TJ}$ that is referred to previously.

$$
V=\frac{\max _{t}\left\{P^{t}-R^{t}\right\}-\min _{t}\left\{P^{t}-R^{t}\right\}}{\left(\left|\operatorname{median}_{t}\left\{T^{\max }\right\}-\operatorname{median}_{t}\left\{T^{\min }\right\}\right|+1\right) * \max _{c}\left\{\max _{t}\left\{P^{t}-R^{t}\right\}-\min _{t}\left\{P^{t}-R^{t}\right\}\right\}}
$$

The value of $\left(P^{t}-R^{\natural}\right)$ is highest in the year a country records the maximum number of progressive events net of regressive events and is at its lowest when a country records the maximum number of regressive transitional justice events net
The denominator of this measure is made up of two parts. The first expression, subtracting $\operatorname{median}_{t}\left\{T^{\text {min }}\right\}$ from median $\left\{T^{\max }\right\}$, accounts for the number of years the country in question took to experience such a policy 
Table 1

Comparison table

\begin{tabular}{|c|c|c|c|}
\hline Countries & TJDB (Lustration) & TJRC (Vetting) & Severity (TJ Vetting) \\
\hline Albania & 2 & 2 & 0.545 \\
\hline Argentina & 2 & 3 & 0.8 \\
\hline Bangladesh & 0 & 0 & 0.5 \\
\hline Benin & 0 & 0 & 0 \\
\hline Bolivia & 0 & 0 & 0 \\
\hline Bosnia and Herzegovina & 3 & 5 & 0.667 \\
\hline Brazil & 0 & 0 & 0.8 \\
\hline Bulgaria & 2 & 4 & 0.588 \\
\hline Burundi & 0 & 0 & 0 \\
\hline Cape Verde & & 0 & 0 \\
\hline Chile & 0 & 0 & 0.667 \\
\hline Colombia & 0 & 0 & 0.5 \\
\hline Comoros & & 0 & 0.5 \\
\hline Croatia & 0 & 0 & 0 \\
\hline Cyprus & & 0 & 0 \\
\hline Czech Republic & 2 & 2 & 0.81 \\
\hline Dominican Republic & 1 & 1 & 0.5 \\
\hline East Timor & 0 & 0 & 0 \\
\hline Ecuador & 0 & 0 & 0 \\
\hline Egypt & 0 & 0 & 0.5 \\
\hline El Salvador & 0 & 0 & 0 \\
\hline Estonia & 0 & 1 & 0.762 \\
\hline Georgia & 0 & 1 & 0.556 \\
\hline Germany & 1 & 2 & 0.8 \\
\hline Ghana & 0 & 0 & 0 \\
\hline Greece & 2 & 5 & 0.842 \\
\hline Grenada & & 0 & 0 \\
\hline Guatemala & 0 & 0 & 0.75 \\
\hline Guinea Bissau & 1 & 0 & 0.6 \\
\hline Guyana & . & 0 & 0 \\
\hline Haiti & 0 & 0 & 0 \\
\hline Honduras & 0 & 0 & 0 \\
\hline Hungary & 1 & 2 & 0.684 \\
\hline India & 0 & 0 & 0.75 \\
\hline Indonesia & 0 & 0 & 0 \\
\hline Kenya & 0 & 1 & 0.667 \\
\hline Kosovo & . & 0 & 0 \\
\hline Latvia & & 1 & 0.778 \\
\hline Lebanon & 0 & 0 & 0 \\
\hline Lesotho & 0 & 0 & 0 \\
\hline Liberia & 0 & 2 & 0 \\
\hline Lithuania & 1 & 4 & 0.75 \\
\hline Macedonia & 0 & 1 & 0.636 \\
\hline Madagascar & 0 & 0 & 0 \\
\hline Malawi & 0 & 0 & 0 \\
\hline Mali & 0 & 0 & 0.833 \\
\hline Mexico & 0 & 0 & 0.667 \\
\hline Moldova & 0 & 0 & 0.5 \\
\hline Mongolia & . & 0 & 0 \\
\hline Montenegro & & 0 & 0 \\
\hline Nepal & 0 & 2 & 0.5 \\
\hline Nicaragua & 0 & 0 & 0.5 \\
\hline Niger & 0 & 0 & 0 \\
\hline Nigeria & 1 & 1 & 0.5 \\
\hline Northern Ireland & & 0 & 0.5 \\
\hline Pakistan & 0 & 0 & 0.5 \\
\hline Palestine & & 0 & 0 \\
\hline Panama & 0 & 0 & 0.667 \\
\hline
\end{tabular}

(continued) 
Table 1

Comparison table (continued)

\begin{tabular}{lccc}
\hline Countries & TJDB (Lustration) & TJRC (Vetting) & Severity (TJ Vetting) \\
\hline Paraguay & 1 & 1 & 0.833 \\
Peru & 0 & 0 & 0.5 \\
Philippines & 0 & 1 & 0 \\
Poland & 1 & 2 & 0.625 \\
Portugal & 1 & 2 & 0.706 \\
Romania & 0 & 2 & 0.692 \\
Russia & 0 & 0 & 0.3 \\
Sao Tome and Principe & 0 & 0 & 0 \\
Senegal & 0 & 0 & 0 \\
Serbia & 0 & 1 & 0.833 \\
Sierra Leone & 0 & 0 & 0 \\
Slovakia & $\cdot$ & 1 & 0.714 \\
Slovenia & $\cdot$ & 1 & 0.429 \\
South Africa & 0 & 0 & 0 \\
South Korea & 0 & 0 & 0.5 \\
Spain & 1 & 0 & 0.5 \\
Sri Lanka & 0 & 0 & 0 \\
Sudan & 1 & 0 & 0 \\
Taiwan & 0 & 0 \\
Thailand & 0 & 0 \\
Tunisia & 0 & 0 & 0.667 \\
Turkey & 0 & 0 & 0 \\
Ukraine & 1 & 1 & 0.692 \\
Uruguay & $\cdot$ & 0 & 0.5 \\
Venezuela & 0 & 0 & 0.5 \\
Zambia & 0 & 0 &
\end{tabular}

\section{Figure 5}

\section{Measure of volatility}

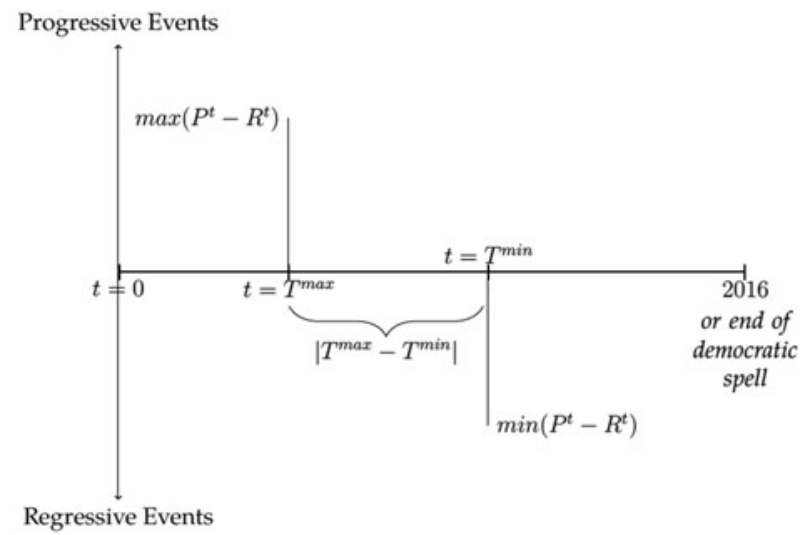

swing. We want our volatility measure to increase when the number of these years is lower. At the same time, because the maximum and minimum net values could be associated with more than a single year in a country's posttransition history, we take the median year of all maximum net values and the median year of all minimum net values. Since it does not matter whether the uptick in progressive events precedes or succeeds the uptick in regressive events, we take the absolute value of the differences between the two medians. The second expression in the denominator is a weight ensuring that our measure does not exceed 1. It is simply the largest possible swing across all countries in our data (hence the subscript " $c$ " in the maximum expression: $\left.\max _{c}\left\{\max _{t}\left\{P^{t}-R^{t}\right\}-\min _{t}\left\{P^{t}-R^{t}\right\}\right\}\right)$.

The operation of this seemingly complex measure is conveniently illustrated in figure 5 . To make the figure more transparent, we refrained from including multiple years with the maximum and minimum scores of $\left(P^{t}-R^{\star}\right)$, which are labeled at $T^{\max }$ and $T^{\min }$, respectively, in the figure.

$V$ takes the value of zero when a country does not experience any policy swing in transitional justice and approaches 1 when a country exhibits a significant policy swing in a relatively brief time period. Note that whether a country has a measure of volatility at all will vary from one TJ mechanism to another, as the measure can only be applied to countries that exhibited both progressive and regressive personnel $\mathrm{TJ}$ events. Countries that did not implement any transitional justice of a given type, and those that only had progressive or only regressive events, do not have volatility measures as they cannot experience policy swings. This limitation is why figure 6, illustrating the 


\section{Figure 6 \\ Volatility of truth commissions}

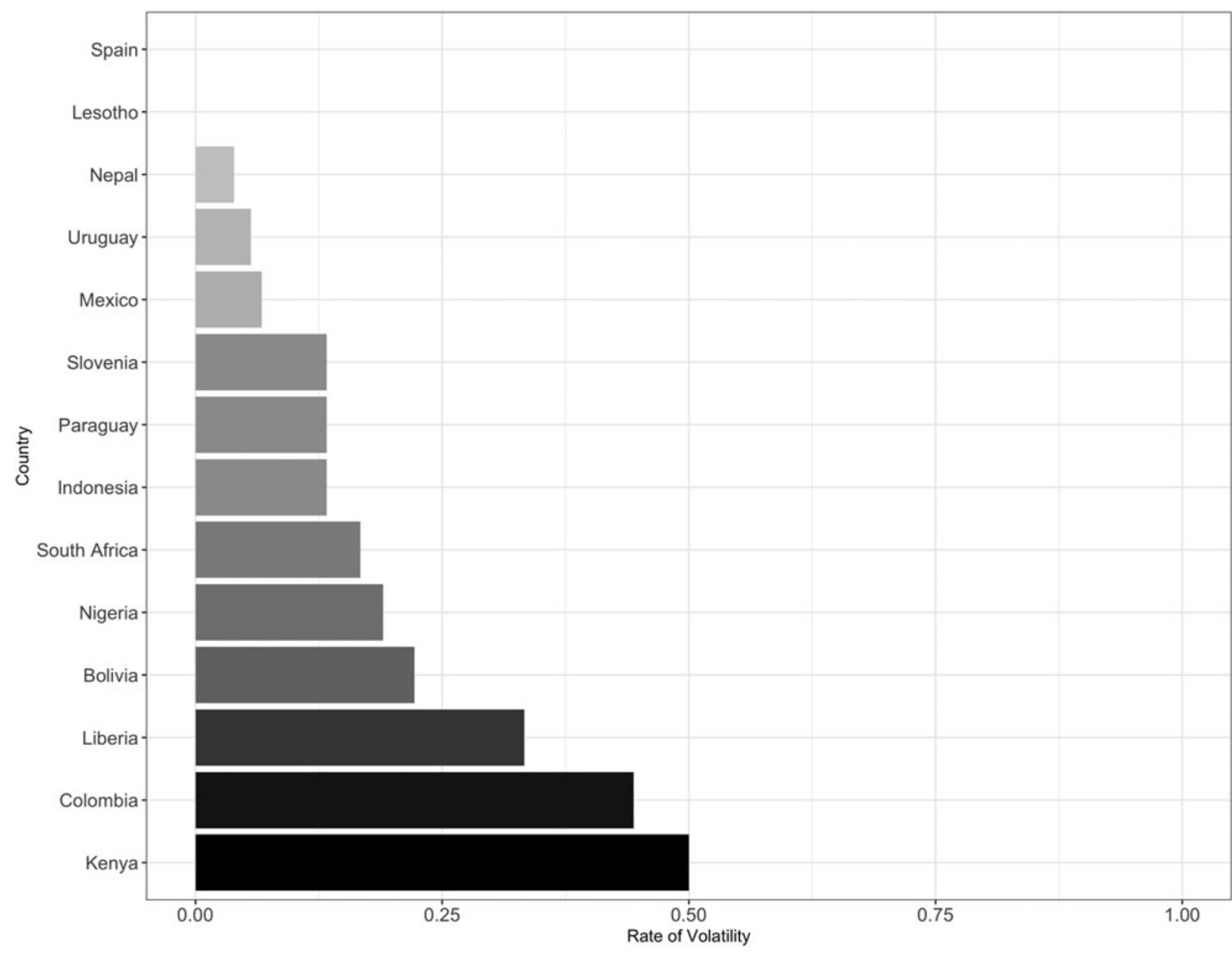

application of volatility to the case of truth commissions, has fewer cases than the figures illustrating severity and urgency.

Volatility, by far the most complex of the three measures presented here, exposes the potentially greatest problem arising from a coding procedure limited to whether or not a country experienced a personnel transitional justice procedure. First consider the two cases of Lesotho and Nepal, where volatility is very low. These two countries' volatility values approximate situations where transitional justice is implemented once and for all; thus, the coding is not affected by the time at which data were collected. Contrast this with highly volatile countries, such as Liberia, Colombia, and Kenya, where transitional justice is implemented at one point only to be revoked shortly after. In such countries, the coding of the presence or absence of the transitional justice mechanism is highly dependent on the moment in time when the data collection took place.
We elaborate on two examples: Lesotho and Kenya. In 2000, Lesotho's government established a Commission of Inquiry to look into the election-related violence of 1998 (Morpheme/Survivor (Maseru) 2000a). While the establishment of the Commission was challenged in court that same year, it ultimately finished its work, releasing a report in October 2001 (Morpheme/The Survivor (Maseru) 2000b, 2002). In Kenya, however, initiatives to establish a permanent truth commission body in the aftermath of the 2002 democratic transition failed alongside the 2005 draft constitution (Human Rights Watch 2008). In Kenya, however, initiatives to establish a permanent truth commission body in the aftermath of the 2002 democratic transition failed alongside the 2005 draft constitution (Human Rights Watch 2008). Years later, in the wake of the 2007-2008 postelection violence, a commission of inquiry (CIPEV) and subsequent truth commission were set up to investigate what happened (International Center for Transitional Justice 
2011). While the CIPEV report was adopted by parliament, the legislative body ultimately sought to censor the Truth, Justice, and Reconciliation Commission report, amending the initial law establishing the body to require implementation of the report only after consideration by parliament (International Center for Transitional Justice 2014).

\section{Applying the Measures in a Regression Framework}

Although the data presented justify our decision to disaggregate personnel transitional justice into events across time and into specific types of mechanisms, we have thus far offered little in terms of links between these events and the replacement of authoritarian elites, which is our motivating question: does reckoning with former authoritarian elites and their collaborators play a role in authoritarian reversals? This section fills the lacuna by applying our data and measures in a regression framework.

The power of former authoritarian elites extends beyond the life span of an authoritarian regime. Autocrats may be well positioned to capture state resources at the time of democratic transition, which they can then use in a clientelistic fashion to stay in power (Brun and Diamond 2014; Haggard and Kaufmann 2016; Albertus and Menaldo 2014). The out-going autocrats' access to resources can be cut off if they or their successors are voted out of office following the transition to democracy. Various cases from around the world demonstrate, however, that this removal may only be temporary (Kitschelt et al. 1999). Grzymala-Busse (2002), for instance, attributes the revival of successor authoritarian parties to the organizational advantage authoritarian parties hold over parties that are new to the party system. This organizational advantage allows them to make better use of state resources when they eventually do find themselves in government. Effective personnel transitional justice institutions are often portrayed as the last resort to curb autocrats' unfair advantage. Indeed, scholars of transitional justice have argued that its mechanisms should undercut the privileged position of members or parties of the former autocrats, their collaborators, or their enforcement apparatuses (Stan et al. 2009; David 2011; Vinjamuri and Snyder 2004; Escribà-Folch and Wright 2015).

In light of this discussion, personnel transitional justice may plausibly be interpreted as a mechanism preventing former authoritarian elites from holding on to such economic resources. Therefore, a variable measuring the association between economic wealth and political power is an ideal candidate for a dependent variable operationalizing the effects of transitional justice on the quality of democratic representation. Additionally, given the temporal nature of our data, an ideally suited dependent variable also measures this association over time. Fortunately, the Varieties of Democracy Expert Survey (VDem) contains such a measure (Coppedge et al. 2017a).
Called "Political Power distributed by Socio-economic status" (PdSES), the variable is based on the following question posed to V-Dem experts: "Is political power distributed according to socioeconomic position?" 25 In his clarification note, John Gerring elaborates that the measure was designed to gauge the extent to which inequalities translate into political power (Coppedge et al. 2017b). ${ }^{26}$ If the goal of personnel transitional justice is to undermine the privileged position of authoritarian elites, this score should increase with the severity of the transitional justice mechanism in question.

We present a series of regressions using PdSES as the dependent variable and our measure of severity of the three personnel transitional justice mechanisms-TJ vetting, purges, and truth commissions - as the independent variables. In addition, we make use of the information we collected on timing of democratic transition and on the years lapsed since the transition. To create the dependent variable PdSES, the V-Dem team converted the ordinal expert answers to an interval scale. We truncated the V-Dem panel to match countries and years that occur in our dataset and added measures of transitional justice severity for all three mechanisms.

Using OLS is not warranted due to the nested structure of our data, which is a panel containing all the years since the transition for eighty-three countries. ${ }^{27}$ OLS, due to the homoscedasticity assumption, produces unbiased results only when errors are distributed independently across observations (Raudenbush and Bryk 2002). However, in our case, the errors, like years since transition, are clustered by country. Hence, a multilevel (or mixed) model is the most appropriate. The details of how this multilevel model was developed have been relegated to online appendix A. The results of our regressions are presented in table 2 .

Model 1 from table 2 is a so-called null model, which only includes the separate error terms for calculating how much of the variation to be explained comes from differences in PdSES within countries instead of between countries. It indicates that $0.81 \%$ of the variation is explained by differences between countries. We conclude from this that a hierarchical model is justified in this instance (Finch, Bolin, and Kelley 2014). The next model (2) is a random intercept model that incorporates one explanatory variable at the country level: "years after the transition." We decided to include the variable because TJ vetting severity, like all of our measures of transitional justice, is measured at the country level.

Model 3 differs from model 2 only in its error structure. While model 2 admits only random intercepts, model 3 also admits random slopes. In other words, in model 2 , only the intercept can vary within countries; the slopes are all constrained to the same country-specific slope. In model 3, both the slopes and intercepts can vary within countries. In model 4 , we additionally include the 
Table 2

Regression results (Dependent variable: Power distributed by socioeconomic status)

\begin{tabular}{|c|c|c|c|c|c|c|}
\hline & Model 1 & Model 2 & Model 3 & Model 4 & Model 5 & Model 6 \\
\hline Years after & 一 & $0.000(0.001)$ & $-0.009^{\star}(0.005)$ & $-0.010^{*}(0.005)$ & $\begin{array}{c}-0.010^{\star *} \\
(0.005)\end{array}$ & $-0.009^{*}(0.005)$ \\
\hline TJ Vetting Sev. & 一 & 一 & - & $0.665^{\star \star}(0.259)$ & - & 一 \\
\hline Purges Sev. & 一 & 一 & 一 & - & $0.541(0.336)$ & - \\
\hline Truth Com Sev. & - & - & - & - & - & $0.117(0.248)$ \\
\hline Constant & $\begin{array}{c}0.605^{\star \star *} \\
(0.083)\end{array}$ & $\begin{array}{c}0.601^{\star \star \star} \\
(0.084)\end{array}$ & $\begin{array}{c}0.672^{\star \star \star} \\
(0.102)\end{array}$ & $\begin{array}{c}0.453^{\star \star \star} \\
(0.131)\end{array}$ & $\begin{array}{c}0.590^{\star \star \star} \\
(0.113)\end{array}$ & $\begin{array}{c}0.622^{\star \star \star \star} \\
(0.148)\end{array}$ \\
\hline \multicolumn{7}{|l|}{$\begin{array}{l}\text { Random } \\
\text { Effects: }\end{array}$} \\
\hline Intercept (Var.) & 0.561 & 0.560 & 0.837 & 0.791 & 0.805 & 0.856 \\
\hline $\begin{array}{l}\text { Years after } \\
\text { (Var.) }\end{array}$ & - & - & 0.002 & 0.002 & 0.002 & 0.002 \\
\hline Residual (Var.) & 0.135 & 0.135 & 0.070 & 0.070 & 0.070 & 0.070 \\
\hline Observations & 1875 & 1875 & 1875 & 1875 & 1875 & 1875 \\
\hline
\end{tabular}

Note: ${ }^{*} p<0.1,{ }^{* \star} p<0.05,{ }^{* \star *} p<0.01$

severity of TJ vetting (abbreviated as "TJ Vetting Sev.") as an explanatory variable at the country level. Models 5 and 6 show the results after including the severity of purges and the severity of truth commissions, respectively.

In the model that tests the effect of TJ vetting severity, as much as $92 \%$ of the variation in the dependent variable is explained by variation between countries as opposed to within countries, again justifying our use of a hierarchical model. The effect of TJ vetting severity of PdSES is quite high (.722), positive, and significant. As higher values of PdSES indicate a weaker correlation between wealth and political status, this is a normatively desirable result. It appears that more severe TJ vetting indeed disentangles economic and political privilege, which are fused under authoritarianism.

In contrast, a similarly structured model used for predicting the effect of purges on PdSES (model 5) shows no significant effect of this personnel transitional justice mechanism. The insignificant effect is also smaller -only .56 compared to .722 of TJ vetting severity. ${ }^{28} \mathrm{In}$ the case of truth commission severity (model 6), the effect is still insignificant and, at .108, even smaller.

Interestingly, years after transition also has a significant effect on political power distributed by socio-economic status, but the effect is negative. That is, with every year lapsed since the democratic transition, more political power is distributed according to economic wealth and status. The effect, however, is very small. The passage of an additional year lowers the PdSES score only by .01 units on the 5-point scale that measures PdSES.

Although this offers some support for our initial hypothesis-one of the personnel transitional justice mechanisms, TJ vetting, weakens the association between economic wealth and political power-the others do not seem to matter. This could be attributed to the fact that our outcome variable is, like vetting, very elite-focused. While truth commissions and purges can limit the return of former authoritarian elites and perpetrators to positions of power, they both cast a broad net: truth commissions extend their focus beyond elites, and purges rely on the attribution of collective responsibility. In order to dig deeper into the mechanism of TJ vetting - the only significant mechanism within our regression-we perform one more exercise in disaggregation, explained in the next section.

\section{Disaggregating Personnel Transitional Justice Further}

Among elites who sustained the former authoritarian regime are persons whose involvement in it is known, such as high ranking officials of authoritarian parties, and those whose identity is unknown, such as secret police informers, and people who spied on their friends, family, and co-workers. Revealing the truth, and the associated bans on holding public office, can have a different effect in those two cases. In the case of unknown collaborators, if a TJ vetting law is not put in place, politicians who collaborated with the authoritarian regime or committed atrocities in secret can be blackmailed with the threat of revealing these actions by those with credible access to such "skeletons in the closet" (Nalepa 2010b; Ang and Nalepa 2019). Needless to say, if the public still pays attention to what happened in the past, the revelation of such "skeletons" could end a politician's career. In return for their silence, individuals in possession of credible evidence of "skeletons in the closet" can demand rents or policy concessions. Regardless of the currency in which the ransom is paid by the blackmailed politician, the quality of democracy suffers.

The mechanism behind the vetting of known collaborators is different. Since getting rid of members who ran the agencies of the former authoritarian regime is similar to getting rid of bureaucrats, one can think of this vetting process as the reverse of a delegation problem. If a newly 
elected politician comes to office and vets the administrative apparatus so thoroughly that he gets rid of all bureaucrats with policy expertise, he is forced to implement policy in inherently uncertain conditions. Without the expertise of people who ran the agencies under the ancien régime, he cannot know how policy implementation will be affected by states of the world unknown to him. Conversely, a reduction of the severity of vetting can be thought of as the equivalent of delegation to an agent who is equipped with expertise and thus able to adjust policies to the state of the world. The dilemma facing new democracies transitioning from autocracy or domestic conflict is obvious to any student of principal-agent models. The agent-in this case, the staff member of the authoritarian agency — may have preferences that are so misaligned with those of the principal (the new politician) that he will use his expertise to implement policy he himself prefers. On balance, this policy outcome may be worse for the principal than his own implementation, ridden with lack of expertise as it is. Thus, in some circumstances (when preferences are completely misaligned) vetting will have a positive effect on the quality of democracy, but in others (when preferences are only somewhat misaligned) it will reduce the quality of the new democracy.

The intuitions outlined earlier suggest that the mechanism behind vetting of known collaborators is very different from the mechanism behind vetting of unknown collaborators. For this reason, in our next set of regressions, we propose to disaggregate $\mathrm{TJ}$ vetting into:

- TJ vetting of secret collaborators

- TJ vetting of known collaborators

We first provide a definition and illustrative example of each kind of vetting procedure.

Transitional justice vetting of unknown collaborators. Unknown collaborators are those with secret ties to the former authoritarian secret police or those otherwise responsible for human rights violations. TJ vetting of unknown collaborators takes place through, for example, the opening of archives of the secret police of the former authoritarian regime to uncover who worked as a secret collaborator or informer. Proven collaborators are then either explicitly banned from holding office or a position within the state, or revealed as collaborators to the voters, who subsequently decide whether to cast their votes for the compromised politicians.

A classic example of TJ vetting restricted to unknown collaborators is the Polish lustration law, which requires all persons holding or running for public office to declare in advance whether or not they had collaborated with the secret authoritarian police prior to the transition. Information from declarations admitting collaboration is put on the ballot, and voters themselves decide whether to cast their vote on a former collaborator. Negative declarations are sent to a special division of the Institute for National Remembrance, where they are verified against information assembled in the archives of the former secret political police. Proven collaborators who lied on their declarations are banned from running for office for ten years. Although this is the most cited example of TJ vetting of unknown collaborators (Kaminski and Nalepa 2006; Nalepa 2010a, 2012; Letki 2002; Williams, Fowler, and Szczerbiak 2005; Szczerbiak 2002), it is hardly typical; it allows two types of collaborators to escape direct sanctions: (1) the collaborator who admits he worked as a secret collaborator ${ }^{29}$ and (2) the collaborator who failed to own up to his past but was not uncovered.

A more typical vetting law carries with it an explicit sanction for anyone who is proven to have worked for the secret police as an informer (as in Hungary) or who fails to provide evidence of his or her innocence (as in the Czech Republic).

Transitional justice vetting of known collaborators. This type of vetting is typically limited to the top echelon of the hierarchy of the enforcement apparatus. In other words, it discriminates between the leadership of the organization and the rank and file. A good illustration of a leadership purge is the Bulgarian Panev Law, passed by the Bulgarian National Assembly on December $91992 .{ }^{30}$ Among its many provisions, the law prohibited from holding positions in "Executive Bodies of Scientific Organizations and the Higher Certifying Commission" people who had taught at the Communist Academy for Social Sciences and Social Management and those who had taught history of communist parties, Leninist or Marxist philosophy, political economy, or scientific communism. All persons covered by the law had to provide written statements regarding their prior employment and party activities. A refusal to provide such a statement was regarded as an admission of guilt. According to its author, Mr. Georgi Panev, the underlying idea behind the purge "was to bar persons of the higher totalitarian scientific structures and former collaborators of the former State Security from academic and faculty councils and from the supreme academic awards commission, awarding scientific degrees and other academic qualifications." The reason we do not consider this a purge is that instead of extending collective responsibility to anyone who taught in communist Bulgaria's academic structures, vetting was limited to those who chose to lecture at the schools training communist cadres.

We can observe the usefulness of disaggregating $\mathrm{TJ}$ into dealing with known forms of collaboration with the ancien régime (or engagement in known human rights violations) and dealing with secret forms of collaboration (or engagement in human rights violations that have not been revealed) in figure 7 below. The left panel of the figure plots the total number of progressive transitional justice events net of regressive events as a function of time 
Figure 7

Disaggregating transitional justice data
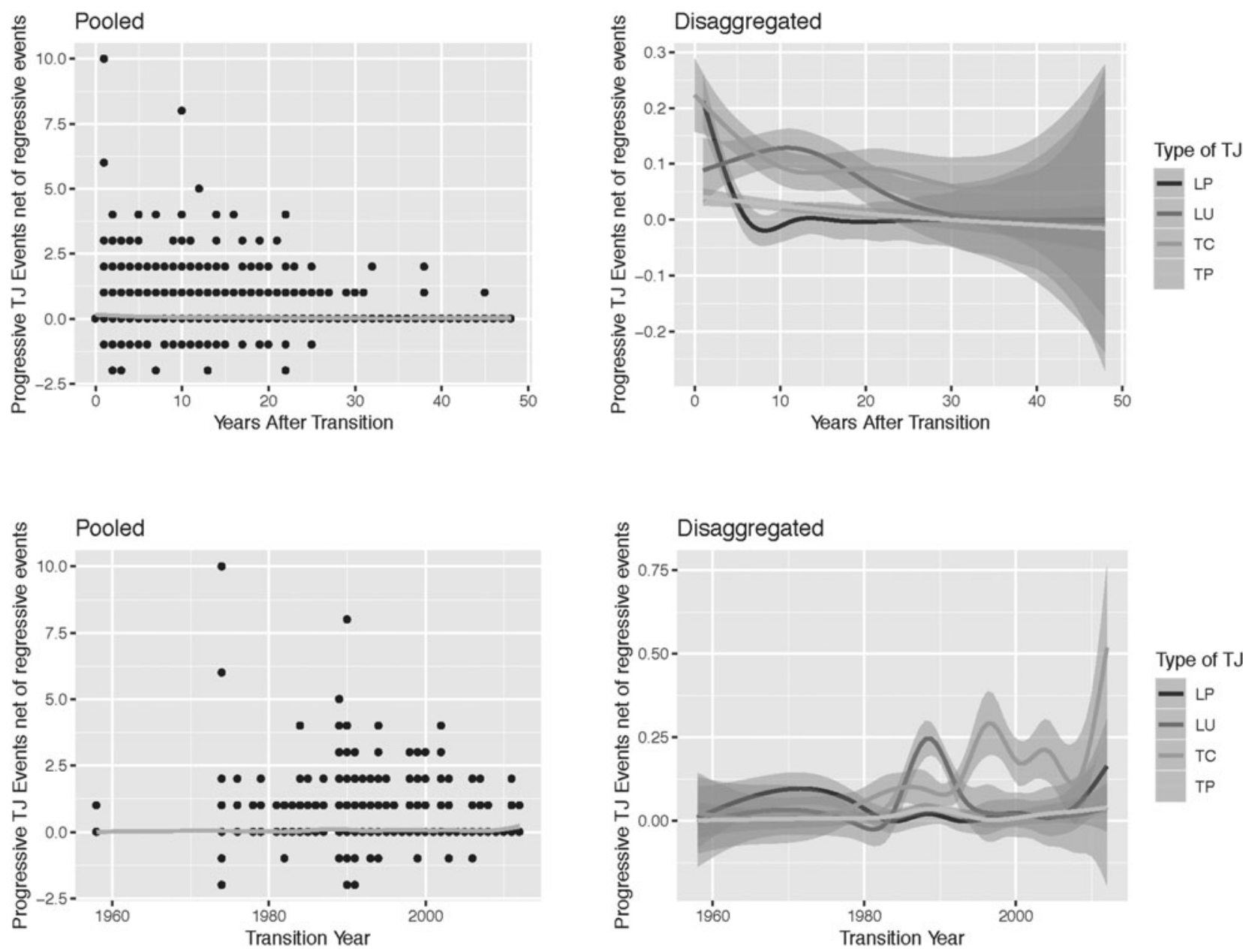

Table 3

Regression results using disaggregated data (Dependent variable: Power distributed by socioeconomic status)

\begin{tabular}{lccc}
\hline & Model 7 & Model 8 & Model 9 \\
\hline Years after & $-0.010^{\star}(0.005)$ & $-0.010^{\star \star}(0.005)$ & $-0.009^{\star}(0.005)$ \\
TJ Vetting Sev. (Pooled) & $0.665^{\star \star}(0.259)$ & - & - \\
TJ Vetting Sev. (Unknown) & - & $0.605^{\star \star}(0.239)$ & - \\
TJ Vetting Sev. (Known) & $0.453^{\star \star \star}(0.131)$ & $0.520^{\star \star \star}(0.115)$ & $0.179(0.241)$ \\
Constant & 0.791 & 0.760 & \\
Random Effects: & 0.002 & 0.002 & 0.842 \\
Intercept (Var.) & 0.070 & 0.070 & 0.002 \\
Years after (Var.) & 1875 & 1875 & 0.070 \\
Residual (Var.) & & & 1875 \\
Observations & &
\end{tabular}

Note: ${ }^{*} p<0.1,{ }^{* *} p<0.05,{ }^{* * *} p<0.01$ 
Table 4 Correlation matrix of severity measures

\begin{tabular}{lcccc}
\hline & TJ vetting (unknown) & TJ vetting (known) & Purges & Truth Commissions \\
\hline TJ vetting (unknown) & 1.00 & 0.16 & 0.22 & 0.14 \\
TJ vetting (known) & 0.16 & 1.00 & 0.48 & -0.13 \\
Purges & 0.22 & 0.48 & 1.00 & -0.03 \\
Truth Commissions & 0.14 & -0.13 & -0.03 & 1.00 \\
\hline
\end{tabular}

\section{Table 5}

\section{ANOVA tests}

\begin{tabular}{lcccccc}
\hline Object & Df & AIC & LogLik & Deviance & Chisq & Pr( $>$ Chisq) \\
\hline Baseline Model 3 (years after) & 6 & 1021.6 & -504.81 & 1009.6 & & \\
Model 8 (TJ Vetting of unknown collaborators) & 7 & 1018.1 & -502.05 & 1004.1 & 5.5113 & $0.01889^{* *}$ \\
Model 9 (TJ Vetting of known collaborators) & 7 & 1023.5 & -504.75 & 1009.5 & 0.1097 & 0.7405 \\
Model 5 (Purges) & 7 & 1021.2 & -503.60 & 1007.2 & 2.4097 & 0.1206 \\
Model 6 (Truth Commissions) & 7 & 1023.4 & 504.75 & 1009.4 & 0.2271 & 0.6337 \\
\hline
\end{tabular}

lapsed since the transition (upper left panel) and as a function of the year in which the transition took place (lower left panel). Here, all personnel TJ events have been pooled, and it appears evident that there is no relationship between personnel $\mathrm{TJ}$ and two variables that ought to be good predictors of TJ: time lapsed since transition and year of transition (Elster 2004; Huntington 1991; Barahona de Brito, González-Enríquez, and Aguilar 2001).

However, if we disaggregate the $\mathrm{TJ}$ mechanisms into purges, truth commissions, TJ vetting of known collaborators, and TJ vetting of unknown collaborators, a clear pattern emerges. Consider first the lower right panel of figure 7 illustrating progressive $\mathrm{TJ}$ events net of regressive events for the four mechanisms as a function of transition year. TJ vetting of unknown collaborators is popular in countries that transitioned around 1990, which tend to be the Eastern European ones (Albania, Bulgaria, East Germany, Estonia, Hungary, Latvia, Poland, Slovakia, and Slovenia), as previous scholarship has speculated. Note, however, that there are also instances of TJ vetting of unknown collaborators in other countries. A deeper look into our data reveals that they are Argentina, Spain, and Guatemala. There is also an uptick in truth commissions around the beginning of the third wave of democratization, but in contrast to TJ vetting, truth commission events trend upwards again in countries with mid-1990s transitions, as well as in countries transitioning around $2010 .^{31}$ This is consistent with what we know from the scholarship on truth commissions:

Truth commissions abound in South America (Paraguay, Ecuador, Peru) and Africa (Kenya, South Africa and Liberia); they can also be found in Indonesia and East Germany (United States Institute of Peace 2011a, 2011b, 2011c, 2011d, 2011e, 2011f, 2011h, 2011i; Gibson 2006).

The story with purges and TJ vetting of known collaborators is quite different. First, the occurrence of purges is flat across the range of transition years in our dataset. If they do occur, they occur in the immediate aftermath of the democratic transition (as indicated by the slight uptick on the left end of the upper right panel of figure 7). TJ vetting of known collaborators, on the other hand, seemed to have been more popular at the beginning of the Third Wave transitions (in Latin American countries that transitioned in the 1970s and 1980s), and their popularity seems to have increased again after 2005. As in the case of purges, they are concentrated in the early post-transition years.

The upper panel of figure 7 shows that the timing of TJ vetting of unknown collaborators clearly differs from the timing of purges and of $\mathrm{TJ}$ vetting of known collaborators. Whereas the latter take place in the immediate aftermath of transitions to democracy, TJ vetting of unknown collaborators peaks about ten years following the transition. Truth commissions are implemented soon after the transition or conflict termination but continue to be implemented longer than purges or $\mathrm{TJ}$ vetting of unknown collaborators.

In sum, patterns of purge activity and TJ vetting of known collaborators are not the same as patterns of $\mathrm{TJ}$ vetting of unknown collaborators and truth commission activity. Similar inferences can be drawn from the GIScoded version of our data in the form of world maps illustrating all three of our measures. Geocoded values of 
severity, volatility, and urgency for TJ vetting of unknown collaborators, truth commissions, purges, and $\mathrm{TJ}$ vetting of known collaborators are provided in online appendix B. ${ }^{32}$

The regression table corroborates this intuition. For comparison's sake, we have included model 4 from table 2, that is, the regression with the pooled category of TJ vetting, as model 7. Models 8 and 9 have this independent variable separated into two categories: TJ vetting of known and unknown collaborators and perpetrators of human rights violations.

The results in model 8 in particular suggest that the TJ vetting of unknown collaborators is the driver behind TJ vetting having a significant effect on the relationship between wealth and the distribution of political power. ${ }^{33}$ That coefficient remains significant (though slightly smaller), while the coefficient on TJ vetting of known collaborators (model 9) completely loses significance. This supports our initial theory about the differential effects of vetting that reveals new information about the nature of collaboration with the former authoritarian regime or behavior under conflict. Furthermore, it is clear that the differential effect in our regression is not the result of time lapsed since the transition for two reasons. First, we measure severity at the country level as a proportion of progressive TJ vetting events over all events, progressive and regressive. Second, and more importantly, this effect holds even after accounting for years lapsed since the transition.

In this set of regressions, just as in the previous ones, presented in table 2 , we decided to forgo including all the transitional justice mechanisms in one regression, because some of them are highly correlated with one another, as table 4 indicates.

Instead of saturating the regression model, we can compare all the models against one another using an ANOVA test. In this test, we compare the baseline model (model 3 from table 3), which uses only years since the transition as a predictor, against each of the models that additionally incorporate the severity of each transitional justice mechanism. The results indicate that only the model including the severity of $\mathrm{TJ}$ vetting of unknown collaborators is significantly different (with a p-value of .019) from the baseline model in its predictive power.

Table 5 also presents the log-likelihood of all models as well as the Akaike Information Criterion. As a general rule of thumb, the smaller these values are, the better the fit of the model. The values of the measures corresponding to the TJ vetting of unknown collaborators model are clearly smaller than those of the others.

\section{Conclusion}

We have introduced a new dataset on transitional justice, that is, on how new democracies recovering from authoritarianism or civil war deal with members of and collaborators with former authoritarian regimes. Our dataset is innovative in a number of ways. First, it records personnel transitional justice as events unfolding over time following the year of transition. This allows us to account for instances of delayed $\mathrm{TJ}$ as well as of $\mathrm{TJ}$ reversals. It also allows us to design innovative ways of measuring TJ severity and volatility. We encourage scholars to use our personnel $\mathrm{TJ}$ events data as building blocks for constructing new measures motivated by their specific theoretical interests.

A second innovation of our dataset is that it parses out similar yet distinct ways of dealing with personnel of the former authoritarian regime. First, it separates purges from $\mathrm{TJ}$ vetting. In a second step, it distinguishes between two forms of TJ vetting: (1) the removal from office of elites whose actions under the former authoritarian regime were known or perpetrators who committed crimes that are common knowledge, and (2) vetting that relies on revealing information that was kept secret.

We also summarize an argument according to which the TJ vetting of unknown collaborators ought to be more conducive to democratic stability than purges. This argument follows from an assumption that revealing secret information prevents blackmail by those with access to skeletons in the closets of former collaborators and perpetrators who now hold positions of power (Ang and Nalepa 2019). In contrast, the only outcome achieved by purges and the vetting of known collaborators is the removal from office of elites whose expertise could be useful to new democracies. To test this hypothesis about the differential effects of TJ vetting we regress a V-Dem variable that operationalizes the turnover of authoritarian elites ${ }^{34}$ on the severity of truth commissions, purges, and TJ vetting. First, we find support for the theory that the severity of $\mathrm{TJ}$ vetting indeed improves the turnover of authoritarian elites, but no such support for the other forms of personnel transitional justice. Second, upon disaggregating TJ vetting into mechanisms dealing with known and unknown collaborators, we only find this effect in TJ dealing with unknown collaborators.

Future research could operationalize the power of authoritarian elites more directly by, for instance, tracing the extent to which authoritarian elites reproduce themselves under the new democratic conditions. Future research could also extend the data collection back to 1918 to incorporate countries from the second wave of democratization, especially those in Western Europe. A third innovation could include applying our technique to events associated with trials, thus creating a time series of progressive and regressive trial events. Given the extensive literature on the effects of criminal trials as part of transitional justice, it would be fascinating to compare the effects of trials to the effects of $\mathrm{TJ}$ vetting of elites. 


\section{Notes}

1 See, for instance, Mallinder 2008, Olsen, Payne, and Reiter 2010b, and most notably Sikkink and Walling 2007, Dancy and Wiebelhaus-Brahm 2017, and the ongoing efforts of the Transitional Justice Research Collaborative (TJRC), Dancy and Montal 2017, and Dancy and Michel 2016.

2 For other excellent arguments of why limiting the focus of TJ to trials is misleading see Murphy 2017.

3 As an example of a failed apology, consider Alexander Kwasniewski's recognition of Jews murdered in Jedwabne, a Polish town under the occupation of Nazi Germany. Kwasniewski apologized on behalf of the Polish people, but the apology failed at reconciling Jews and Poles because Kwasniewski stressed that the truth of what happened in Jedwabne was yet been established (Keesing's Record of World Events 2001). As an example of a successful apology, consider the one by Roman Herzog, issued while attending the fiftieth anniversary of the Warsaw Uprising in 1994, for the suffering Germany caused Poland during World War II.

4 Indeed, most contributions to the lustration literature suggest that this kind of TJ policy is limited to postcommunist Europe; De Greiffand Mayer-Rieckh 2007; Ellis 1996; Closa Montero 2010; Letki 2002; Stan 2013; Stan and Nedelsky 2015.

5 We note that Olsen, Payne, and Reiter 2010a only include truth commissions in regressions as explanatory variables, but even these are marginally significant for only one type of outcome variables-variously constructed terror scales.

6 David defines lustration as a "special public employment law that stipulates the conditions for the access of persons who worked for or collaborated with the political or repressive apparatus of socialist regimes to certain public positions in new democracies."

7 The TJDB includes data on five transitional justice mechanisms including amnesties, trials, truth commissions, lustrations, and reparations. The Transitional Justice Research Collaborative covers amnesties, trials (including domestic, foreign, international and civil), vetting, truth commissions, reparations, and customary justice

8 In line with Horne 2017b we will use the term TJ vetting as synonymous with lustration.

9 Childs and Popplewell 2016 report that

most of the Stasi employees had to turn to some other means of earning their living. However a significant number did find reemployment in private security. In Saxony, it was reported that more than 500 ex-Stasi operatives had been taken over by the police. This includes 161 former full time Ministry for State Security employees and 262 unofficial collaborators. In addition, 370 ex-members of the DDR criminal police were in employment in 1994 (195).
10 Since our dataset extends to post-conflict situations, we broaden the set of offenses subject to vetting to include perpetrators of human rights violations.

11 The full name was "Law On Genocide and Crimes against Humanity Committed in Albania during Communist Rule for Political, Ideological or Religious Motives."

12 Specifically, it was established via the Promotion of National Union and Reconciliation Act, passed by the South African parliament in July 1995; United States Institute of Peace 2011j.

13 As testimony to the non-criminal character of the commission's work, consider its chairman's insistence that "the major task of his commission was not to bring the wrongdoers to justice but to find out the truth of the events during the April-May 2010 protests so the public would be informed in order to ensure that incidents of this kind were not repeated"; Rustici and Sander 2012.

14 Examples of such countries include Russia, Egypt, and Thailand.

15 Examples of each includes Cyprus, which is excluded from GWF based on size, and Kenya, which is excluded despite its Post-Election Violence in 20072008. Although the Post-Election Violence in Kenya was excluded from PCJ, it produced numerous domestic transitional justice events, including the creation of a truth commission.

16 A list of these secondary sources is available here: https://tinyurl.com/ybmcj7hf.

17 Note that this categorization of events is not intended to reflect the normative implications of a given event. The striking down of a TJ law that violates individual protections, for example, may be a normatively positive event, but it nevertheless weakens the TJ process. Thus, all such events are categorized as "regressive" events.

18 We mention, for instance, that among the events included in our chronologies are ones that could not be classified as purges, vetting, or truth commissions. These were labeled "non-events" and include trials, amnesties, and victim compensation. Other researchers may want to create their own categories out of these events, a project made possible by our organization of the chronologies. Moreover, our technique of labeling events as progressive or regressive could be fruitfully applied to criminal trials. The initiation of an investigation, along with an indictment, could be the first progressive event in a trial proceeding. Reducing the number of counts on which a defendant would be charged would be a regressive event, as would acquittal or the commuting of a sentence.

19 Nigeria's time series is censored at 2016, because our data collection ends with 2016. In other words, we are not 
capturing the events that will happen at a future time. Censorship is a problem for all countries that do not end with an authoritarian reversal by 2016, but is most acute in the case of states that transitioned more recently.

20 We clarify that in all three measures subscripts do not represent exponents, but time indices.

$21 T^{N}$ need not be the same as 2016, as illustrated by the case of Thailand, which experienced a military coup in 2014.

22 In countries like Thailand, $T^{1}$ will be subtracted from the year of the authoritarian reversal rather than from 2016.

23 We code the data beginning with the first year after the transition, which is consistent with the fact that the first progressive event has to take place after the transition.

24 Any measure seeking to show the variation between these two extreme cases should note the direction of the timing of TJ. Therefore, we use the language of "urgency" and "delay" to explain this measure rather than simply "timing" because the value of the measure increases when the TJ process is implemented shortly after the transition.

25 Answers to the question were distributed along a 5point scale. The possible answers included:

(0) "Wealthy people enjoy a virtual monopoly on political power. Average and poorer people have almost no influence";

(1) "Wealthy people enjoy a dominant hold on political power. People of average income have little say. Poorer people have essentially no influence";

(2) "Wealthy people have a very strong hold on political power. People of average or poorer income have some degree of influence but only on issues that matter less for wealthy people";

(3) "Wealthy people have more political power than others. But people of average income have almost as much influence and poor people also have a significant degree of political power"; and

(4) "Wealthy people have no more political power than those whose economic status is average or poor. Political power is more or less equally distributed across economic groups" (Coppedge et al. 2017b).

26 PdSES is also a particularly reasonable measure of quality of democracy for our purposes because while it measures an important aspect of democracy, it is unlikely to be correlated with rule of law, which could also affect the implementation of transitional justice.

27 The reason our number of cases drops from 84 to 83 is that Grenada is not coded in V-Dem.

28 Since severity of all mechanisms is measured on the same 0-1 scale, such comparisons of magnitude of the coefficients are warranted.

29 See Nalepa 2008 for a discussion of whether a positive declaration is, indeed, not a sanction.
30 The full name of the bill was "Law for Temporary introduction of Additional Requirements for Members of Executive Bodies of the Scientific Organizations and the Higher Certifying Commission."

31 These include the Arab Spring countries-Tunisia and Egypt - as well as several countries in South and Southeast Asia.

32 They are also available at an interactive website: https://tinyurl.com/ybmcj7hf.

33 Recall that higher values of PdSES mean lower correlation of wealth with political power.

34 Recall that this is measured by the extent to which economic wealth translates into political power; Coppedge et al. 2017b.

\section{Supplementary Materials}

A. Statistical Appendix

B. GIS Appendix

To view supplementary material for this article, please visit https://doi.org/10.1017/S1537592719000756

\section{References}

Albertus, Michael and Victor Menaldo. 2014. "Gaming Democracy: Elite Dominance during Transition and the Prospects for Redistribution." British Journal of Political Science 44(3): 575-603.

Alivizatos, Nicos C. and P. Nikiforos Diamandouros. 1997. Politics and the Judiciary in the Greek Transition to Democracy. Notre Dame, IN: University of Notre Dame Press.

Anaba, Innocent. 2001. "Nigeria: Appeal Court Asked To Determine Legality Of Oputa Panel." The Vanguard Daily, February 28 (https://allafrica.com/stories/ 200102280103.html), accessed October 18, 2018.

Bakiner, Onur. 2016. Truth Commissions: Memory, Power, and Legitimacy. Philadelphia: University of Pennsylvania Press.

Barahona de Brito, Alexandra, Carmen GonzálezEnríquez, and Paloma Aguilar, eds. 2001. The Politics of Memory: Transitional Justice in Democratizing Societies. Oxford: Oxford University Press.

Bermeo, Nancy. 2016. "On Democratic Backsliding." Journal of Democracy 27(1): 5-19.

Binningsbø, Helga Malmin, Cyanne E Loyle, Scott Gates, and Jon Elster. 2012. "Armed Conflict and PostConflict Justice, 1946-2006: A Dataset.” Journal of Peace Research 49(5): 731-40.

Borchert, Jurgen. 2006. Die Zusammenarbeit des Ministeriums fur Staatssicherheit (MFS) mit dem sowjetischen $K G B$ in den 70er und 80er Jahren: ein Kapitel aus der Geschichte der SED-Herrschaft. Münster: LIT Verlag.

Brun, Diego Abente and Larry Diamond. 2014. Clientelism, Social Policy, and the Quality of Democracy. Baltimore, MD: Johns Hopkins University Press. 
Childs, David and Richard Popplewell. 2016. The Stasi: The East German Intelligence and Security Service. London: Palgrave Macmillan.

Cinar, Ipek. 2017. "Democracy Dismantled: Strategic Choices of the Would-be Autocrats." Working Paper, University of Chicago.

Closa Montero, Carlos. 2010. "Study on How the Memory of Crimes Committed by Totalitarian Regimes in Europe Is Dealt with in the Member States." Madrid: Institute for Public Goods and Policy.

Congreso de los Diputados, Comisión de Cultura. 2013. "161/002111." Boletín Oficial de Las Cortes Generales $\mathrm{D}(360)$ : 27-28.

Coppedge, Michael. 2012. Democratization and Research Methods. Cambridge, UK: Cambridge University Press. Coppedge, Michael, John Gerring, Staffan I. Lindberg, Svend-Erik Skaaning, Jan Teorell, David Altman, Michael Bernhard, M. Steven Fish, Adam Glynn, Allen Hicken, Carl Henrik Knutsen, Joshua Krusell, Anna Luhrmann, Kyle L. Marquardt, Kelly McMann, Valeriya Mechkova, Moa Olin, Pamela Paxton, Daniel Pemstein, Josefine Pernes, Constanza Sanhueza Petrarca, Johannes von Romer, Laura Saxer, Brigitte Seim, Rachel Sigman, Jeffrey Staton, Natalia Stepanova, and Steven Wilson. 2017a. "V-Dem Country-Year/ Country-Date Dataset v7.1." University of Gothenburg: Varieties of Democracy Institute.

Coppedge, Michael, John Gerring, Staffan I. Lindberg, Svend-Erik Skaaning, Jan Teorell, Michael Bernhard, David Altman, M. Steven Fish, Adam Glynn, Allen Hicken, Carl Henrik Knutsen, Kyle L. Marquardt, Valeriya Mechkova Kelly McMann, Pamela Paxton, Daniel Pemstein, Laura Saxer, Brigitte Seim, Rachel Sigman, and Jeffrey Staton. 2017b. "V-Dem Codebook v7.1.". University of Gothenburg: Varieties of Democracy Institute.

Dancy, Geoff and Veronica Michel. 2016. "Human Rights Enforcement from Below: Private Actors and Prosecutorial Momentum in Latin America and Europe." International Studies Quarterly 60(1): 173-88.

Dancy, Geoff and Florencia Montal. 2017. "Unintended Positive Complementarity: Why International Criminal Court Investigations May Increase Domestic Human Rights Prosecutions." American Journal of International Law 111(3): 689-723.

Dancy, Geoff and Eric Wiebelhaus-Brahm. 2018. "The Impact of Criminal Prosecutions during Intrastate Conflict." Journal of Peace Research 55(1): 47-61.

David, Roman. 2011. Lustration and Transitional Justice: Personnel Systems in the Czech Republic, Hungary, and Poland. Philadelphia: University of Pennsylvania Press. De Greiff, Pablo and Alexander Mayer-Rieckh. 2007. Justice as Prevention: Vetting Public Employees in Transitional Societies. New York: Social Science Research Council.
Ellis, Mark S. 1996. "Purging the Past: The Current State of Lustration Laws in the Former Communist Bloc." Law and Contemporary Problems 59(4): 181-96.

Elster, Jon. 2004. Closing the Books: Transitional Justice in Historical Perspective. Cambridge, UK: Cambridge University Press.

Escribà-Folch, Abel and Joseph Wright. 2015. "Human Rights Prosecutions and Autocratic Survival." International Organization 69(2): 343-73.

Finch, W. Holmes, Jocelyn E. Bolin, and Ken Kelley. 2014. Multilevel modeling using $R$. New York: Routledge.

Geddes, Barbara, Joseph Wright, and Erica Frantz. 2014. "Autocratic Breakdown and Regime Transitions: A New Data Set." Perspectives on Politics 12(2): 313-31.

Gibson, James L. 2006. "Overcoming Apartheid: Can Truth Reconcile a Divided Nation?" Annals of the American Academy of Political and Social Science 603(1): 82-110.

Goertz, Gary. 2006. Social Science Concepts: A User's Guide. Princeton, NJ: Princeton University Press.

Grzymala-Busse, Anna M. 2002. Redeeming the Communist Past: The Regeneration of Communist Parties in East Central Europe. New York: Cambridge University Press.

Haggard, Stephen and Robert Kaufmann. 2016. Dictators and Democrats: Masses, Elites, and Regime Change. Princeton, NJ: Princeton University Press.

Hatschikjan, Magarditsch, Dušan Reljić, and Nenad Šebek. eds. 2005. "Disclosing Hidden History: Lustration in the Western Balkans." Thessaloniki: Center for Democracy and Reconciliation in Southeast Europe. Belgrade: Cicero.

Hayner, Priscilla B. 1994. "Fifteen Truth Commissions1974 to 1994: A Comparative Study." Human Rights Quarterly 16(4): 597-655.

- 2001. Unspeakable Truths: Confronting State Terror and Atrocity. Hove, UK: Psychology Press.

- 2011. Unspeakable Truths: Transitional Justice and the Challenges of Truth Commissions. New York:

Routledge.

Horne, Cynthia. 2017a. "Vetting, Purges, and Lustration: Measurement Choices and Empirical Implications." Conference Proceedings of the American Political Science Association Meeting, September 2.

-2017b. Building Trust and Democracy in Transition: Assessing the Impact of Transitional Justice in PostCommunist Countries. Oxford: Oxford University Press. Human Rights Watch. 1991. "Human Rights in PostInvasion Panama: Justice Delayed Is Justice Denied." B304. New York: Human Rights Watch. 2008. "Ballots to Bullets: Organized Political Violence and Kenya's Crisis of Governance.” 20(1A). New York: Human Rights Watch.

Huntington, Samuel P. 1991. The Third Wave: Democratization in the Late Twentieth Century. Norman: University of Oklahoma Press. 
International Center for Transitional Justice. 2011. "The Kenyan Commission of Inquiry into Post-Election Violence."

-. 2014. "Kenya TJRC Final Report Deserves Serious Analysis and Action."

Jenne, Erin K. and Cas Mudde. 2012. "Can Outsiders Help?" Journal of Democracy 23(3): 147-55.

Kaminski, Marek M. and Monika Nalepa. 2006. "Judging Transitional Justice: A New Criterion for Evaluating Truth Revelation Procedures." Journal of Conflict Resolution 50(3): 383-408.

Kaminski, Marek M., Monika Nalepa, and Barry O’Neill. 2006. "Normative and Strategic Aspects of Transitional Justice." Journal of Conflict Resolution 50(3): 383-408.

Keesing's Record of World Events. 1974. "Announcement of General Election Date. - Resumption of Party Politics. - Other Internal Developments.” 20: 26781. . 1998. "South Africa." 44: 42536. 2001. "Life Expectancy." 47(7): 44275.

Kitschelt, Herbert, Zdenka Mansfeldova, Radoslaw Markowski, and Gabor Toka. 1999. Post-Communist Party Systems: Competition, Representation, and InterParty Cooperation. New York: Cambridge University Press.

Koehler, John O. 1999. STASI: The Untold Story of the East German Secret Police. New York: Basic Books.

Krauss, Clifford. 2000. "New Argentine President Orders Purge of 'Dirty War' Remnants." New York Times, February 16, 6.

Kreutz, Joakim. 2010. "How and When Armed Conflicts End: Introducing the UCDP Conflict Termination Dataset." Journal of Peace Research 47(2): 243-50.

Letki, Natalia. 2002. "Lustration and Democratisation in East-Central Europe.” Europe-Asia Studies 54(4): 52952.

Lust, Ellen and David Waldner. 2015. "Unwelcome Change: Understanding, Evaluating, and Extending Theories of Democratic Backsliding." US Agency for International Development (https://pdf.usaid.gov/ pdf_docs/PBAAD635.pdf), accessed October 15, 2018.

Mallinder, Louise. 2008. Amnesty, Human Rights and Political Transitions: Bridging the Peace and Justice Divide. Oxford: Bloomsbury Publishing.

Miller, John. 1998. "Settling Accounts with a Secret Police: The German Law on the Stasi Records." EuropeAsia Studies 50(2): 305-30.

Mopheme/The Survivor (Maseru). 2000a. "Lesotho: 1998 Revisited-Do You Know Anything?" Mophemel The Survivor (Maseru), April 5 (https://allafrica.com/ stories/200004050126.html), accessed October 15, 2018.

_. 2000b. "Lesotho: 'Sephetho Commission' Delayed by Court Action." Mopheme/The Survivor (Maseru)
April 26 (https://allafrica.com/stories/

200004260168.html), accessed October 15, 2018.

. 2002. "Lesotho: Senate Motion Calls for Unity." Mopheme/The Survivor (Maseru).

Murphy, Colleen. 2017. The Conceptual Foundations of Transitional Justice. New York: Cambridge University Press.

Nalepa, Monika. 2008. "To Punish the Guilty and Protect the Innocent Comparing Truth Revelation Procedures." Journal of Theoretical Politics 20(2): 22145.

. 2010a. "Captured Commitments: An Analytic Narrative of Transitions with Transitional Justice." World Politics 62(2): 341-80. 2010b. Skeletons in the Closet: Transitional Justice in Post-Communist Europe. New York: Cambridge University Press.

. 2012. "Tolerating Mistakes: How Do Popular Perceptions of Procedural Fairness Affect Demand for Transitional Justice?" Journal of Conflict Resolution 56(3): 490-515.

2013. "Lustration as a Trust-Building Mechanism? Transitional Justice in Poland." In After Oppression, eds. Vasily Popovski and Monica Serrano, 333-362. New York: United Nations Press.

Olsen, Tricia D., Leigh A. Payne, and Andrew G Reiter. 2010a. "The Justice Balance: When Transitional Justice Improves Human Rights and Democracy." Human Rights Quarterly 32(4): 980-1007.

- 2010b. "Transitional Justice in the World, 1970_2007: Insights from a New Dataset." Journal of Peace Research 47(6): 803-09.

Pambazuka News. 2005. "Nigeria: Human Rights Report Released." Pambazuka News. January 27 (https://allafrica.com/stories/200501270670.html), accessed October 15, 2018.

Pinto, Antonio Costa. 2001. "Settling Accounts with the Past in a Troubled Transition to Democracy: The Portuguese Case." The Politics of Memory: Transitional Justice in Democratizing Societies, Alexandra Barahona De Brito, Carmen Gonzalez Enriquez, Paloma Aguilar, 65-91. Oxford: Oxford University Press.

Posner, Eric A. and Adrian Vermeule. 2004. "Transitional Justice as Ordinary Justice." Harvard Law Review 117(3): 761-825.

Raudenbush, Stephen W. and Anthony S. Bryk. 2002. Hierarchical Linear Models: Applications and Data Analysis Methods. Vol. 1. Newbury Park, CA: Sage.

Rustici, Kathleen and Alexandra Sander. 2012. "Thailand's Truth for Reconciliation Commission Issues Final Report." Washington, DC: Center for Strategic International Studies.

Schwartz, Herman. 2000. The Struggle for Constitutional Justice in Post-Communist Europe. Chicago: University of Chicago Press. 
Sedelmeier, Ulrich. 2014. “Anchoring Democracy from Above? The European Union and Democratic Backsliding in Hungary and Romania after Accession." JCMS: Journal of Common Market Studies 52(1): 10521.

Serra, Gilles. 2012. "The Risk of Partyarchy and Democratic Backsliding Mexico's 2007 Electoral Reform.” Taiwan Journal of Democracy 8(1): 93-118.

Siegel, Richard L. 1998. "Transitional Justice: A Decade of Debate and Experience." Human Rights Quarterly 20(2): 431-54.

Sikkink, Kathryn and Carrie Booth Walling. 2007. "The Impact of Human Rights Trials in Latin America." Journal of Peace Research 44(4): 427-45.

Stan, Lavinia. 2013. "Reckoning with the Communist Past in Romania: A Scorecard." Europe-Asia Studies 65(1): 127-46.

Stan, Lavinia and Nadya Nedelsky. 2015. Post-Communist Transitional Justice: Lessons from Twenty-five Years of Experience. New York: Cambridge University Press.

Stan, Lavinia. et al. 2009. Transitional Justice in Eastern Europe and the Former Soviet Union: Reckoning with the Communist Past. New York: Routledge.

Svolik, Milan W. 2017. "When Polarization Trumps Civic Virtue: Partisan Conflict and the Subversion of Democracy by Incumbents." Unpublished Manuscript, Yale University.

Szczerbiak, Aleks. 2002. "Dealing with the Communist Past or the Politics of the Present? Lustration in Postcommunist Poland.” Europe-Asia Studies 54(4): 55372.

Teitel, Ruti G. 2000. Transitional Justice. New York: Oxford University Press.

Thoms, Oskar N. T., James Ron, and Roland Paris. 2010. "State-level Effects of Transitional Justice: What Do We Know?" International Journal of Transitional Justice 4(3): 329-54.

Tillack, Hans-Martin. 2007. "A Tale of Gazoviki, Money and Greed." Stern Magazine, 192.

Todd, Stephen Charles. et al. 2000. Lysias. Vol. 2. Austin: University of Texas Press.

Truth for Reconciliation Commission of Thailand. 2012. "Final Report of Truth for Reconciliation Commission of Thailand (TRCT) July 2010-July 2012. Bangkok.

Ughegbe, Lemmy. 2003. "Nigeria: Oputa Panel Has No Powers-Supreme Court." Vanguard Daily, February 1.

UN Integrated Regional Information Networks (Nairobi). 2011. "Comoros; Missing Guns Delay Demobilization Process." Africa News.

United States Institute of Peace. 2011a. "Truth Commission: Ecuador 96." United States Institute of Peace Truth Commission Digital Archive (https://www. usip.org/publications/1996/09/truth-commissionecuador-96), accessed October 18, 2018. 2011b. "Truth Commission: Ecuador 07." United States Institute of Peace Truth Commission Digital Archive (https://www.usip.org/publications/2007/05/ truth-commission-ecuador-07), accessed October 18, 2018.

. 2011c. "Truth Commission: Germany 92." United States Institute of Peace Truth Commission Digital Archive, (https://www.usip.org/publications/1992/05/ truth-commission-germany-92), accessed October 18, 2018.

2011d. "Truth Commission: Germany 95."

United States Institute of Peace Truth Commission Digital Archive (https://www.usip.org/publications/1995/07/ truth-commission-germany-95), accessed October 18, 2018.

. 2011e. "Truth Commission: Kenya." United States Institute of Peace Truth Commission Digital Archive (https://www.usip.org/publications/2009/07/truthcommission-kenya), accessed October 18, 2018.

2011 f. "Truth Commission: Liberia." United States Institute of Peace Truth Commission Digital Archive. (https://www.usip.org/publications/2006/02/truthcommission-liberia), accessed October 18, 2018. 2011g. "Truth Commission: Nigeria." United States Institute of Peace Truth Commission Digital Archive. (https://www.usip.org/publications/1999/ 06/truth-commission-nigeria), accessed October 18, 2018.

2011h. "Truth Commission: Paraguay." United States Institute of Peace Truth Commission Digital Archive. (https://www.usip.org/publications/2004/06/ truth-commission-paraguay), accessed October 18, 2018.

. 2011i. "Truth Commission: Peru 01." United States Institute of Peace Truth Commission Digital Archive. (https://www.usip.org/publications/2001/07/ truth-commission-peru-01), accessed October 18, 2018.

2011j. "Truth Commission: South Africa." United States Institute of Peace Truth Commission Digital Archive. (https://www.usip.org/publications/1995/12/ truth-commission-south-africa), accessed October 18, 2018.

Van der Merwe, Hugo, Victoria Baxter, and Audrey R. Chapman. 2009. Assessing the Impact of Transitional Justice: Challenges for Empirical Research. Washington, DC: US Institute of Peace Press.

Vinjamuri, Leslie and Jack Snyder. 2004. "Advocacy and Scholarship in the Study of International War Crime Tribunals and Transitional Justice." Annual Review of Political Science 7: 345-62.

Williams, Kieran, Brigid Fowler, and Aleks Szczerbiak. 2005. "Explaining Lustration in Central Europe: A Post-Communist Politics Approach." Democratization 12(1): 22-43. 